\title{
Fruit-feeding butterflies guide of subtropical Atlantic Forest and Araucaria Moist Forest in State of Rio Grande do Sul, Brazil
}

\author{
Jessie Pereira dos Santos ${ }^{1,2}$, Cristiano Agra Iserhard ${ }^{1}$, \\ Melissa Oliveira Teixeira ${ }^{1}$ \& Helena Piccoli Romanowski ${ }^{1}$ \\ ${ }^{1}$ Laboratório de Ecologia de Insetos, Departamento de Zoologia, \\ Universidade Federal do Rio Grande do Sul - UFRGS, Porto Alegre, RS, Brasil \\ ${ }^{2}$ Corresponding author: Jessie Pereira dos Santos, e-mail jessiepereira@gmail.com
}

SANTOS, J.P., ISERHARD, C.A., TEIXEIRA, M.O. \& ROMANOWSKI, H.P. Fruit-feeding butterflies guide of subtropical Atlantic Forest and Araucaria Moist Forest in State of Rio Grande do Sul, Brazil. Biota Neotrop. 11(3): http://www.biotaneotropica.org.br/v11n2/en/abstract?article+bn01311032011

\begin{abstract}
This study presents a compilation of fruit-feeding butterflies species for Rio Grande do Sul Atlantic Forest aiming to be a tool for identification of these lepidopterans from two phytophysiognomies of this biome. Samples were carried out for more than four years with entomological nets and bait traps techniques in areas of Subtropical Atlantic Forest (SAF) and Araucaria Moist Forest (AMF). Seventy-six butterfly species were recorded in this region of Atlantic Forest, 60 species for SAF and 53 for AMF. Fruit-feeding butterflies represent about $50 \%$ of the total species richness of the Nymphalidae recorded for the region, a value of the same order of those found for similar studies in tropical forests regions. Dasyophthalma rusina is a new record for Rio Grande do Sul. Keywords: Atlantic Forest, inventory, field guide, nymphalidae, species richness.
\end{abstract}

SANTOS, J.P., ISERHARD, C.A., TEIXEIRA, M.O. \& ROMANOWSKI, H.P. Guia de borboletas frugívoras das Florestas Ombrófilas Densa e Mista do Rio Grande do Sul, Brasil. Biota Neotrop. 11(3): http://www. biotaneotropica.org.br/v11n2/pt/abstract?article+bn01311032011

Resumo: Este estudo é uma compilação de dados sobre a fauna de borboletas frugívoras na Mata Atlântica no Rio Grande do Sul, e tem como objetivo possibilitar a identificação das espécies ocorrentes em duas formações vegetais deste bioma. Foram realizadas amostragens com as técnicas de rede entomológica e armadilhas de iscas atrativas em áreas de Floresta Ombrófila Densa (FOD) e Floresta Ombrófila Mista (FOM), ao longo de mais de quatro anos. Foram registradas 76 espécies para a Mata Atlântica, sendo 60 espécies para a FOD e 53 para a FOM. As borboletas frugívoras representaram cerca de 50\% da riqueza total de espécies da família Nymphalidae já registradas para a mesma área, valor semelhante foi encontrado para outras regiões de florestas tropicais. Dasyophthalma rusina constitui-se em um novo registro para o Rio Grande do Sul.

Palavras-chave: mata atlântica, inventário, guia de campo, nymphalidae, riqueza de espécies. 


\section{Introduction}

Nymphalidae is divided into two guilds according to adult feeding habits: nectarivorous species, which use flower nectar as a resource, and fruit-feeding species, which feed on decomposing fruits, plant exudates, and mammal excrement (DeVries 1987). Usually, fruit-feeding butterflies comprise between 40 and $55 \%$ of the total diversity of Nymphalidae in a rainforest site (Pinheiro \& Ortiz 1992, Daily \& Ehrlich 1995, DeVries et al. 1999, DeVries \& Walla 2001). Because the guild can be easily sampled with well established protocols using bait traps, it is regarded as a useful tool for monitoring and studies on community structure (Freitas et al. 2003).

Given their charming appeal and importance for the development of conservation and ecological theory, researchers and admirers alike are interested in ways to recognize butterfly species. In fact, butterflies may be used as flagship species in conservation planning and to raise the awareness and attract the public to activities related to the maintenance and preservation of native environments. Field guides provide an invaluable service for these issues, allowing the identification of species and helping to solve doubts with regards to natural history information. In the case of butterflies, use of field guides may lessen the need for unnecessary collections, ensuring the survival of individuals and the performance of faster inventories. This can be of great use for the planning and management of natural reserves, as well as for ecological and taxonomic studies (Brown 1992).

Field guides to insects of tropical regions are scarce and Brazil is no exception. A few pioneer works comprise a guide of the fruit-feeding butterflies of the Reserva Estadual do Morro Grande and Caucaia do Alto (Uehara-Prado et al. 2004) and a guide to the butterflies of Serra do Japi (Brown 1992), both in the state of São Paulo. For southern Brazil, our region of interest, butterfly identification guides are available for provinces in Argentina, such as Misiones and Buenos Aires (Canals 2000, 2003, Klimaitis 2000, Varga 2000, Fernández Díaz 2007, Nuñez-Bustos 2010). Although these guides are useful for the identification of some species, their coverage is far from complete for southern Brazil, especially for the Atlantic Forest.

The Atlantic Forest is classified as a set of forest physiognomies and formations that consists of coastal areas, lowland forests, and high-altitude forest and grasslands. The major forest types in this are Atlantic Forest stricto sensu, Araucaria Moist Forest, Semi-deciduous and Deciduous Seasonal Forests; the associated ecosystems are mangroves, salt marshes, inland swamps, high-altitude grasslands, and coastal and oceanic islands (SOS Mata Atlântica 2010). According to Brown (1996), about two-thirds of the butterfly species in Brazil occur in the Atlantic Forest biome.

The Laboratório de Ecologia de Insetos (Insect Ecology Lab) of the Universidade Federal do Rio Grande do Sul, through the program "Borboletas do Rio Grande do Sul" (Rio Grande do Sul Butterflies) have been studying butterfly fauna in various habitats of the state. The main objective of the program is to contribute to the knowledge on butterfly diversity and to stimulate the conservation of the species and their environments. Consequently, various projects have been developed in Atlantic forest sites, primarily in the Subtropical Atlantic Forest (Iserhard \& Romanowski 2004) and Araucaria Moist Forest (Bond-Buckup 2008, Romanowski et al. 2009, Iserhard et al. 2010, Pedrotti et al. 2011). This work presents a compilation of the data on fruit-feeding butterflies inventoried in these studies and aims to: (i) contribute to the knowledge of the species richness of this group of butterflies in the Atlantic Forest; and (ii) provide an identification guide for the butterflies of this guild in this region.

\section{Material and Methods}

\section{Study areas}

Maquiné municipality $\left(29^{\circ} 35^{\prime} \mathrm{S}\right.$ and $\left.50^{\circ} 16^{\prime} \mathrm{W}\right)$ is located in the northeast region of Rio Grande do Sul, on the slopes of Serra Geral, between the coastal plain and the basaltic plateau, at altitudes varying from 100 to $950 \mathrm{~m}$ a.s.l. The climate is humid subtropical with an average annual temperature higher than $18{ }^{\circ} \mathrm{C}$ (Cfa) (Maluf 2000). The vegetation is predominantly secondary subtropical Atlantic Forest (from now on referred to as SAF), at various degrees of development interspersed with pastures and various crops (for more details see Iserhard \& Romanowski 2004).

The "Floresta Nacional de São Francisco de Paula (FLONA)" $\left(29^{\circ} 24^{\prime} \mathrm{S}\right.$ and $\left.50^{\circ} 22^{\prime} \mathrm{W}\right)$, in the municipality of São Francisco de Paula, is also at the northeastern Rio Grande do Sul, but lays in the basaltic plateau, by the region of "Campos de Cima da Serra" (high altitude grasslands). FLONA has an area of 1606.60 ha at $900 \mathrm{~m}$ a.s.l. The climate is temperate $(\mathrm{Cfb})$ and the average annual temperature is $14.5^{\circ} \mathrm{C}$ (Fernandes \& Backes 1998). The vegetation comprises native Araucaria Moist Forest (from now on referred to as AMF) amidst patches of Araucaria angustifolia (Bertol) Kuntze, Eucalyptus sp., and Pinus sp. plots and areas of grasslands within their boundaries.

\section{Sampling}

Data on the fruit-feeding butterflies were obtained with two techniques: (i) transects with entomological nets; and (ii) bait traps. The first methodology was used to study butterflies belonging to Papilionoidea and Hesperioidea superfamilies in the subtropical Atlantic Forest between 2001 and 2002 (Iserhard \& Romanowski 2004), between 2006 and 2008 (Iserhard 2009) and in the Araucaria Moist Forest between 2006 and 2009 (Iserhard et al. 2010). Sampling was carried out for two hours in each transect, always between 10:00 AM and 4:30 $\mathrm{PM}$, and the sampling effort was measured in net/hour. All butterflies seen were registered and, if necessary for identification, collected with entomological nets. More details on the sampling protocol are provided by Iserhard \& Romanowski (2004) and Paz et al. (2008).

Traps for sampling fruit-feeding butterflies were cylinder-shaped, $110 \mathrm{~cm}$ high and $35 \mathrm{~cm}$ in diameter with voile cloth. Each trap has an internal funnel $22 \mathrm{~cm}$ in diameter to prevent the possible escape of the captured insects (adapted from Uehara-Prado et al. 2005). The traps were attached to a rope at approximately $1.5 \mathrm{~m}$ above ground. The bait was a mixture of sugarcane juice and mashed banana fermented for at least 48 hours and placed on a plate on a metal screen $(50 \times 45 \mathrm{~cm})$ base hanging from a nylon thread ca.5 $\mathrm{cm}$ below the cylinder. The traps were arranged along the transects in sampling units (SU), each consisting of a group of five traps distant approximately $20 \mathrm{~m}$ from each other; the distance between successive SUs along the transect was $100 \mathrm{~m}$. Captured specimens were identified, marked with an overhead projector marker in the wings, and released. Individuals which were difficult to identify were collected for subsequent mounting and identification.

In the SAF region, monthly field surveys expeditions lasted up to six days and were carried out from December 2006 to April 2007. Traps were reviewed once every 24 hours, four times at each sampling occasion. For the AMF region, samplings were performed twice per season from January 2008 to December 2009. At each expedition, the traps were set in the morning of the first day and then checked 3 times at intervals of 24 hours.

Vouchers were deposited at "Coleção de Lepidoptera" of "Departamento de Zoologia" of UFRGS. The nomenclature follows Lamas (2004) and the classification of the subfamilies and tribes follows Wahlberg et al. (2009).

\section{Components of the guide}

A list of fruit-feeding butterfly species of the Atlantic Forest is presented in Table 1. The guide contains color plates with digital images of the species recorded in the study areas. Butterflies are shown in dorsal (D) and ventral view (V), as well as males ( $ठ)$ and females $(+)$ when there is evident sexual dimorphism. Species are represented at $90 \%$ (mentioned as 0:9:1 on Figures) of their natural size, except for those larger species shown on Figures 5,8,9,10 and 11, which appear at only $70 \%$ (mentioned as $0: 7: 1$ on Figures) of their natural size. 
Fruit-feeding butterflies guide of Atlantic Forest

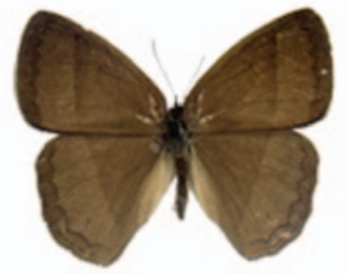

(D)

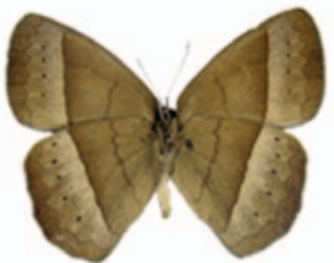

(V)

Capronnieria galesus

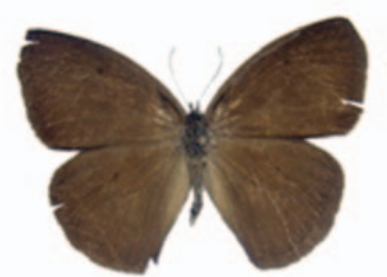

(D)

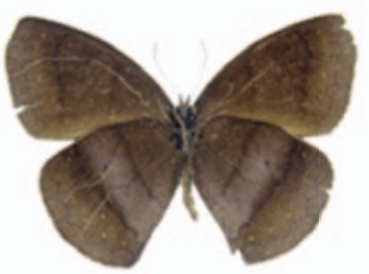

(V)

Forsterinaria quantius

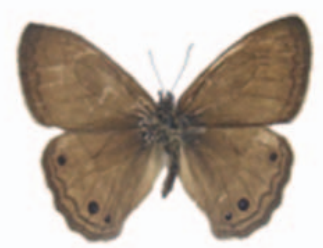

(D)

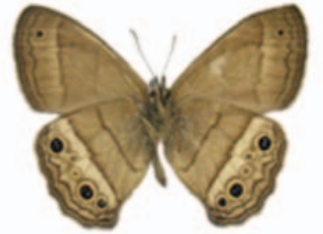

(V)

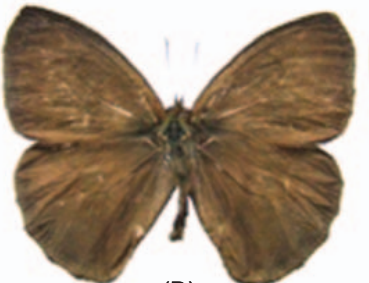

(D)

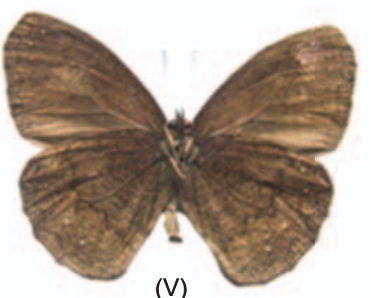

(V)

Forsterinaria necys

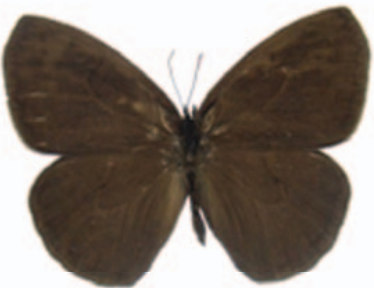

(D)

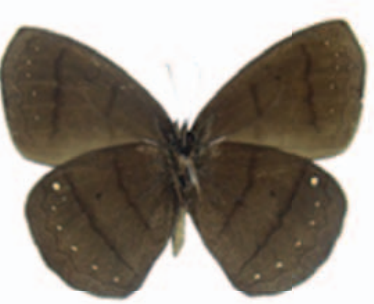

(V)

Forsterinaria quantius $\widehat{\delta}$

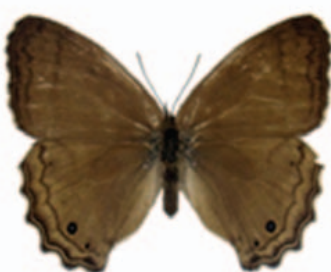

(D)

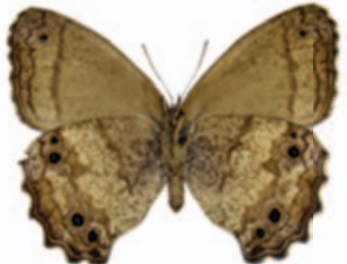

(V)

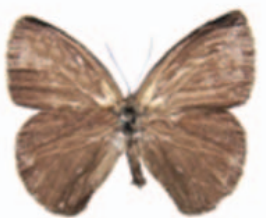

(D)

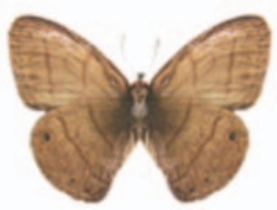

(V)

Hermeuptychia hermes
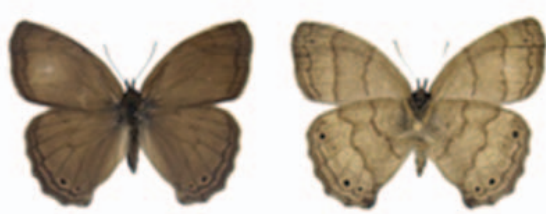

(D)

(V)

Moneuptychia soter

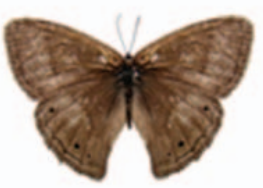

(D)

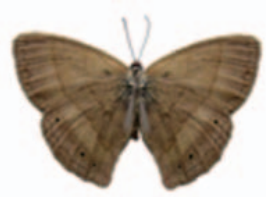

(V)
Moneuptyshia griseldis

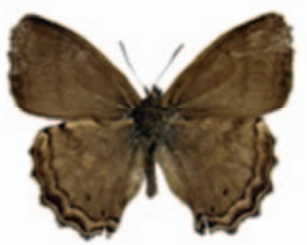

(D)

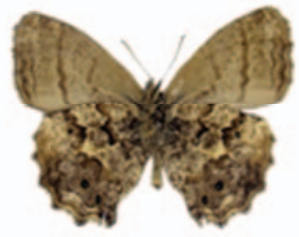

(V)
Moneuptychia paeon

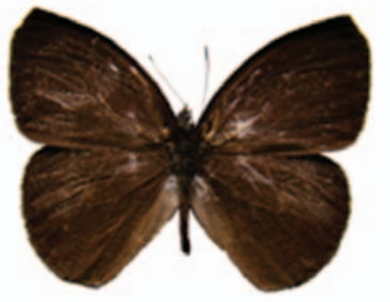

(D)

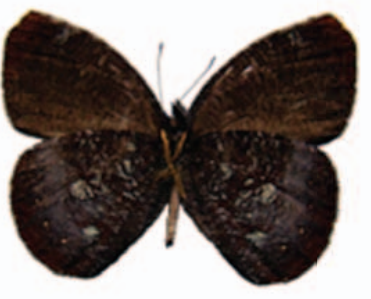

(V)
Godartiana muscosa

Figure 1. Satyrinae (Satyrini) of the Subtropical Atlantic Forest and Araucaria Moist Forest regions of Rio Grande do Sul. 


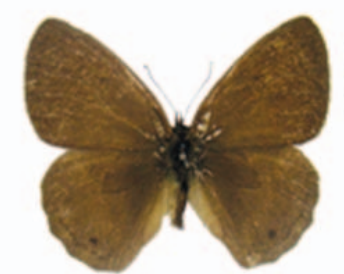

(D) Yphthimoides ochracea $\widehat{\delta}$

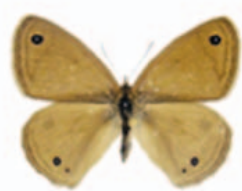

(D)

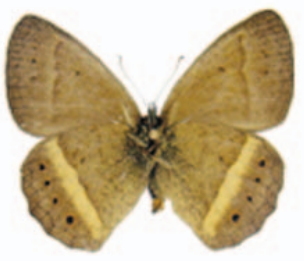

(V)

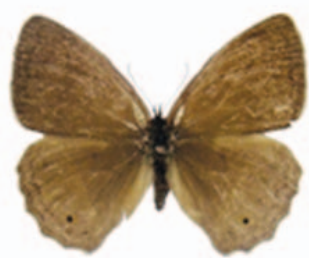

(D)

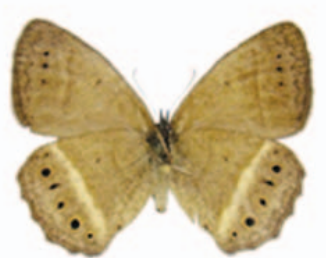

(V) Yphthimoides ochracea 오

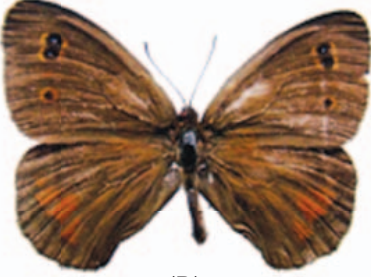

(D)

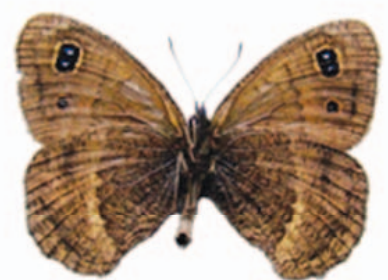

(V)

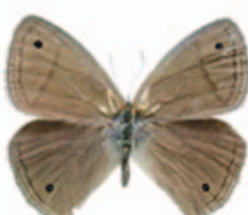

(D)

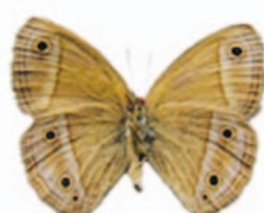

(V)
Pampasatyrus periphas

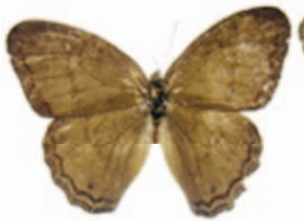

(D)

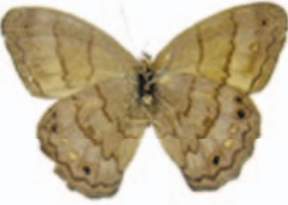

(V)
Paryphthimoides grimon

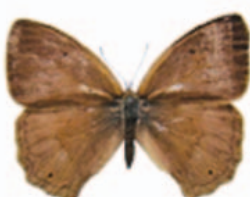

(D)

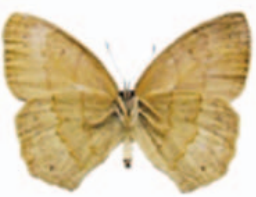

(V)
Paryphthimoides phronius

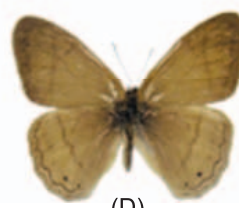

(D)

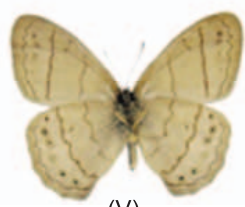

(V)

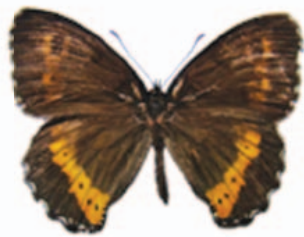

(D)

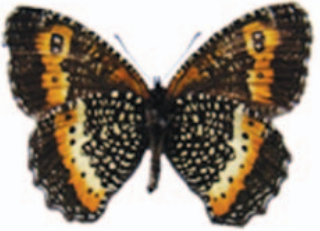

(V)
Pampasatyrus reticulata

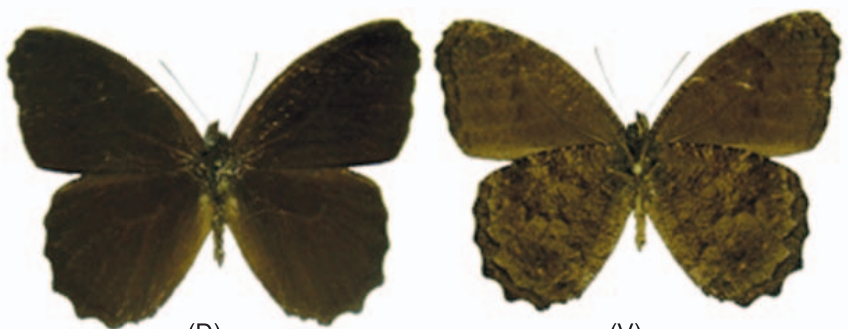

(D)

Praepedaliodes phanias

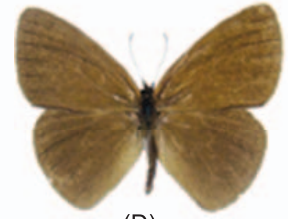

(D)

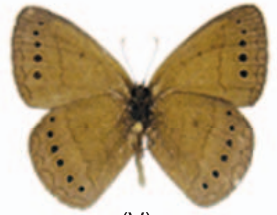

(V)
Prenda clarissa

$(0: 9: 1)$ Paryphthimoides poltys

Figure 2. Satyrinae (Satyrini) of the Subtropical Atlantic Forest and Araucaria Moist Forest regions of Rio Grande do Sul. 
Fruit-feeding butterflies guide of Atlantic Forest

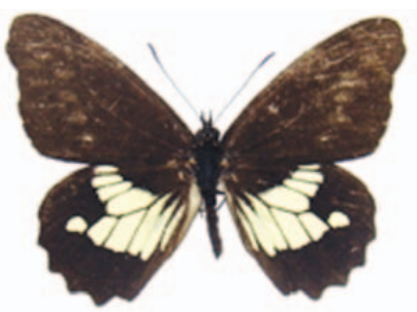

(D)

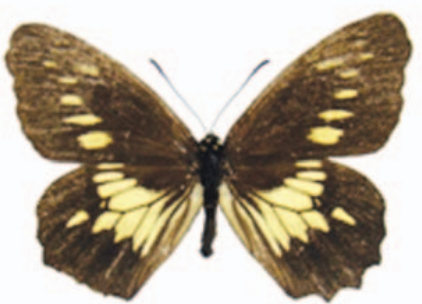

(D)

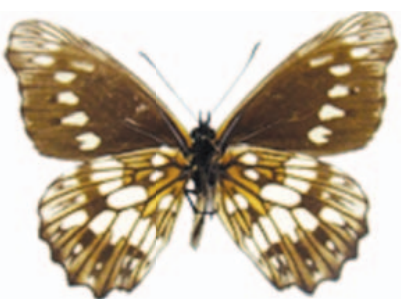

(V)

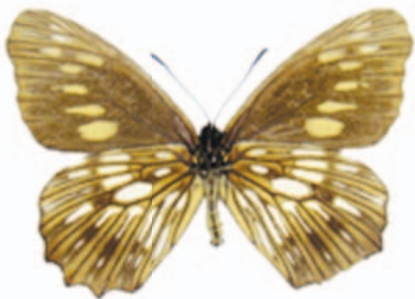

(V)

Eteona tisiphone $q$

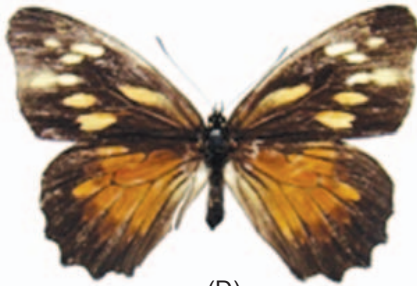

(D)

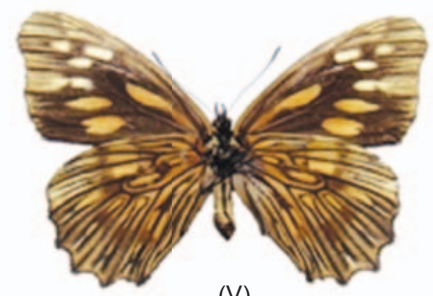

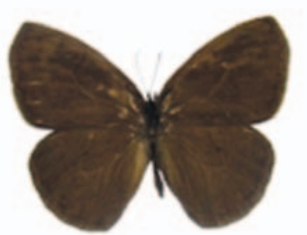

(D)

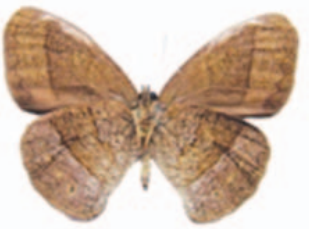

(V1)

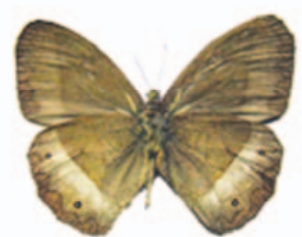

(V2)

Guaianaza pronophila

Eteona tisiphone 우

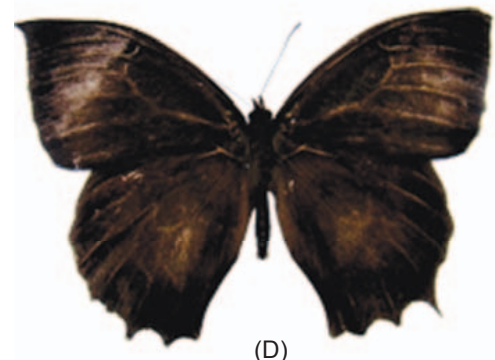

(D)

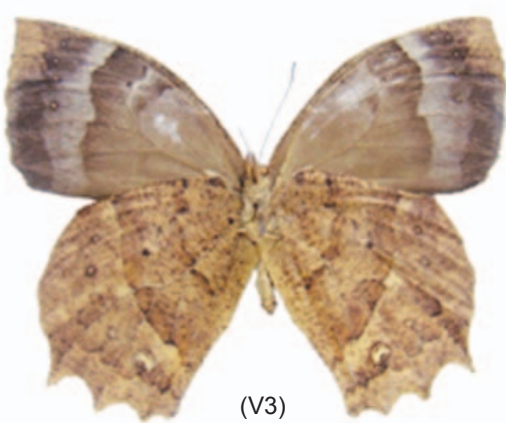

(V)

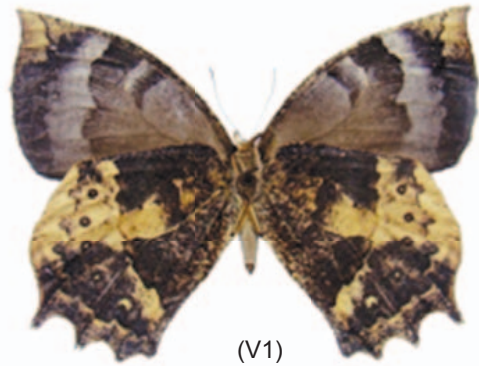

(V1)

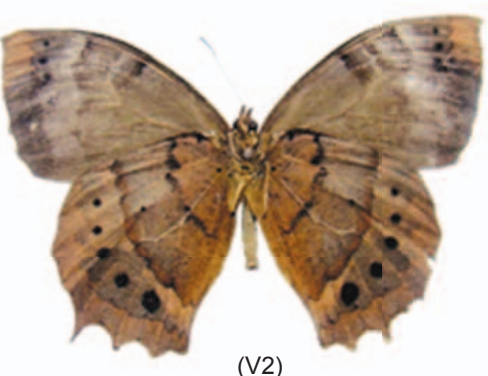

(V2)

$(0: 9: 1)$

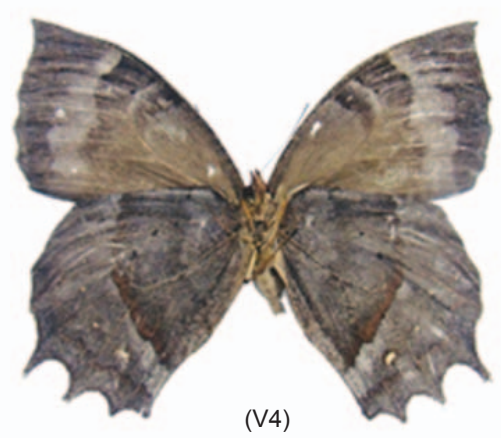

Taygetis ypthima

Figure 3. Satyrinae (Satyrini) of the Subtropical Atlantic Forest and Araucaria Moist Forest regions of Rio Grande do Sul. 

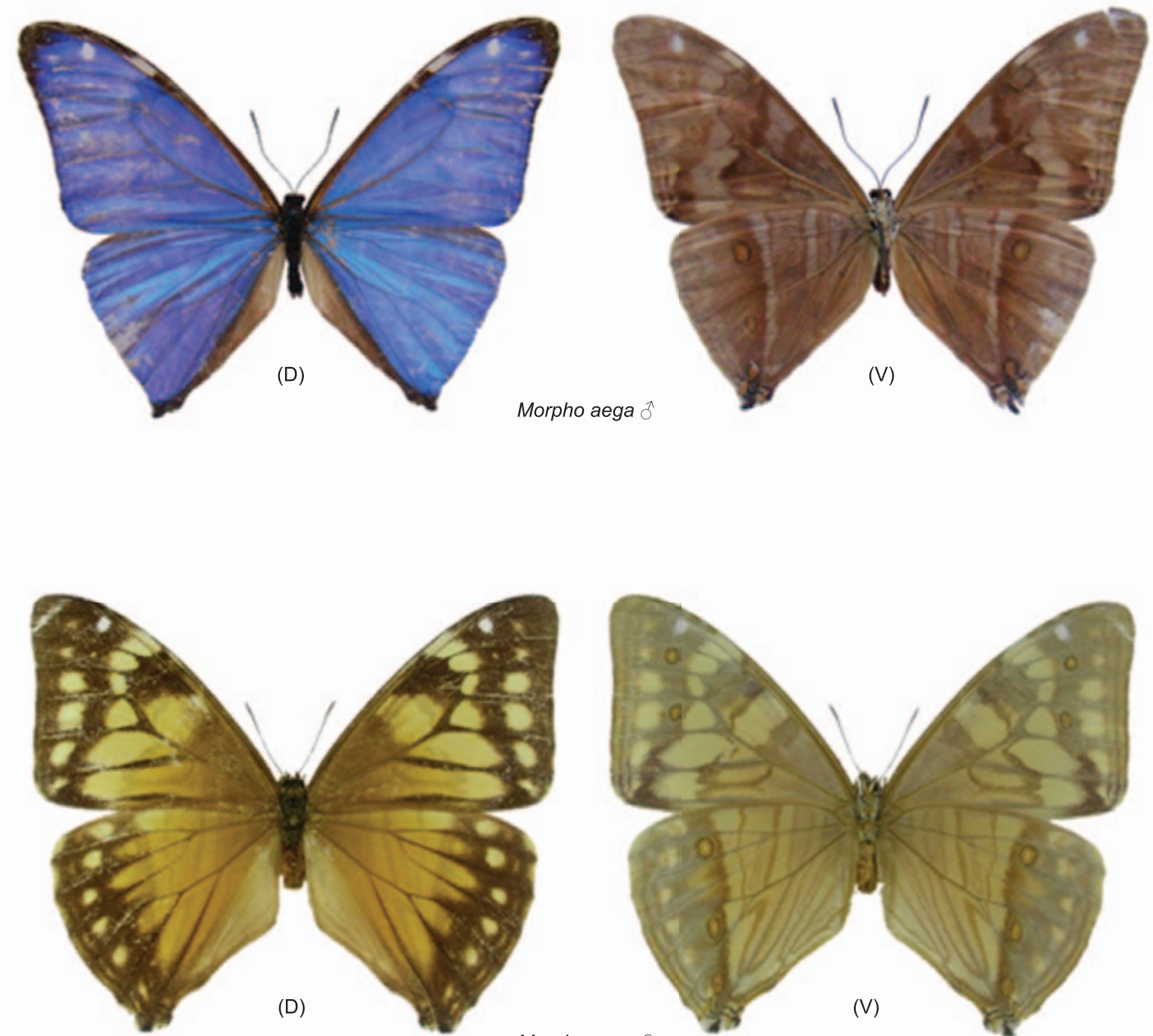

(D)

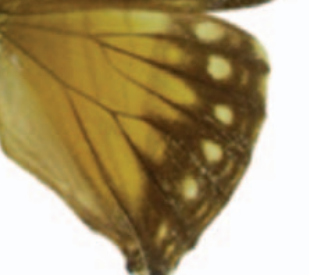

Morpho aega 오

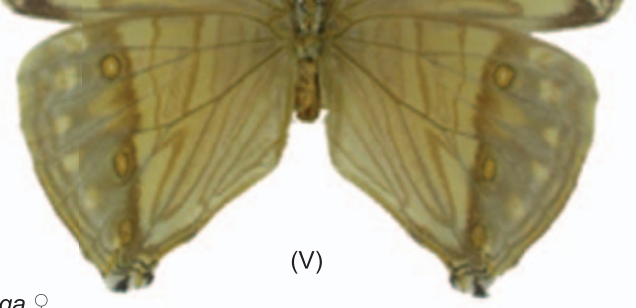

(0:9:1)

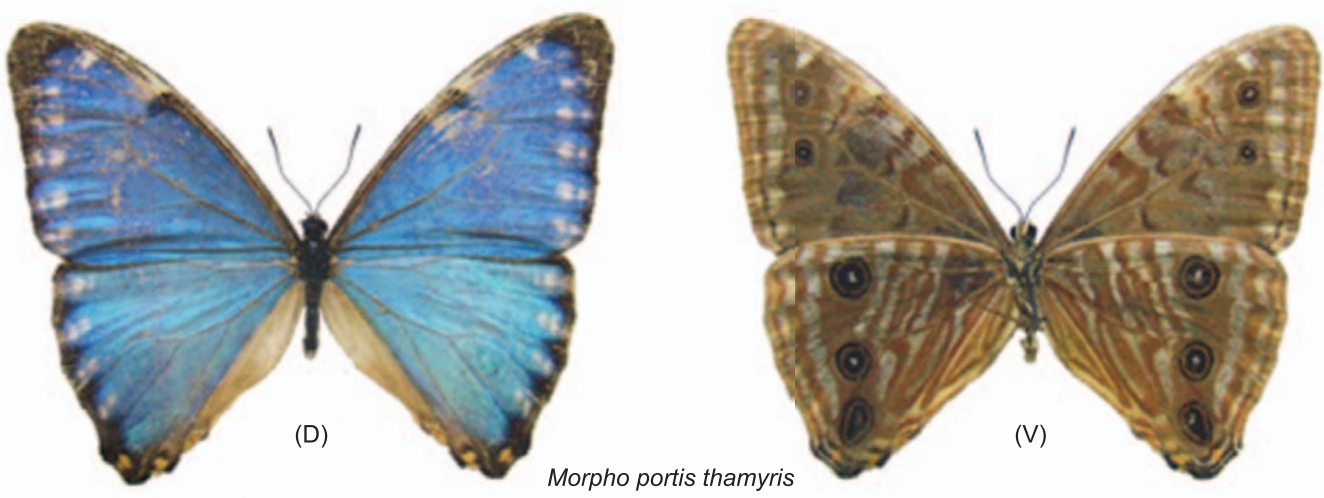

Figure 4. Satyrinae (Morphini) of the Subtropical Atlantic Forest and Araucaria Moist Forest regions of Rio Grande do Sul. 

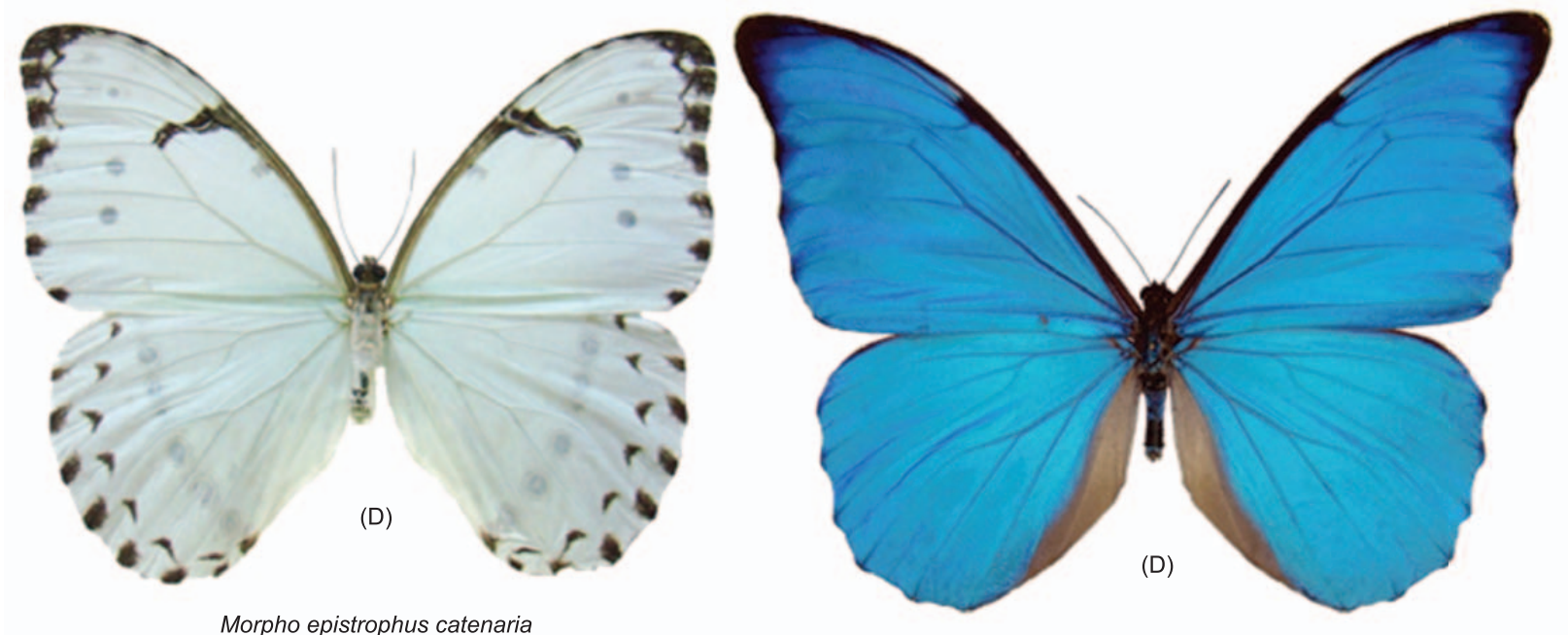

Morpho anaxibia o

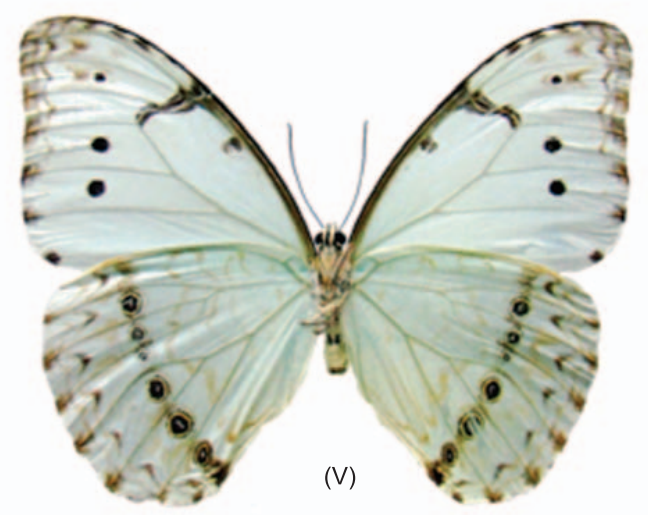

Morpho epistrophus catenaria ô

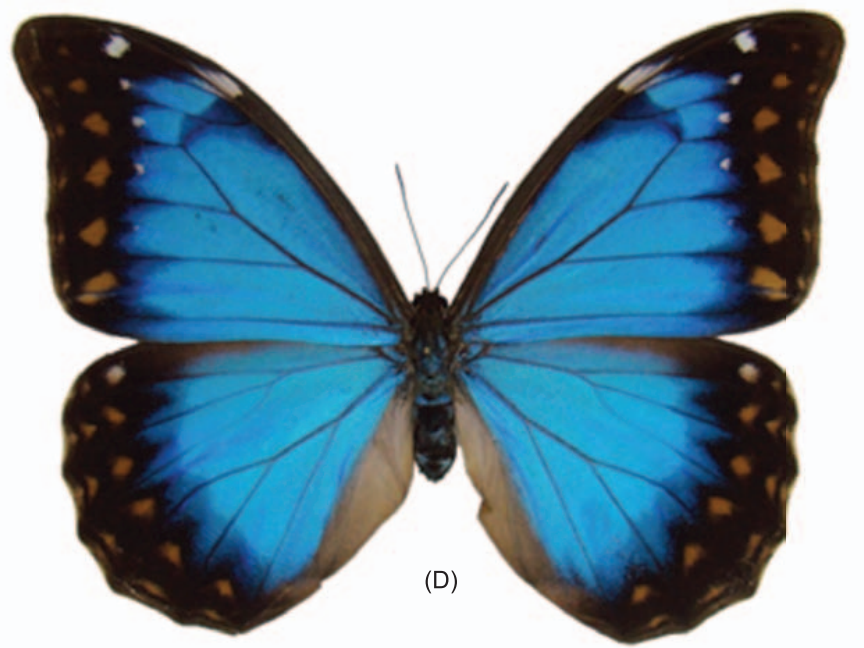

Morpho anaxibia $ᄋ$

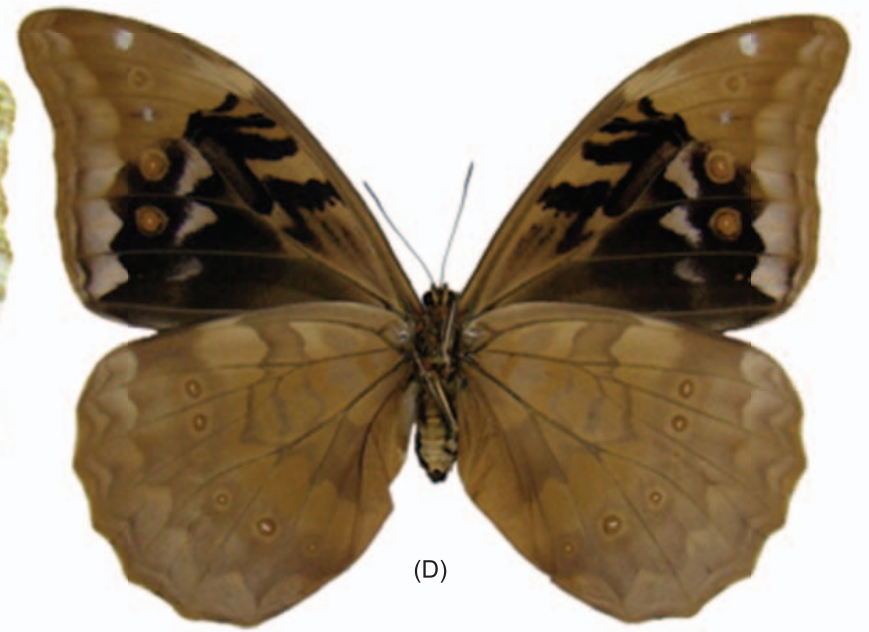

Morpho anaxibia

$(0: 7: 1)$

Morpho epistrophus catenaria $q$

(V)

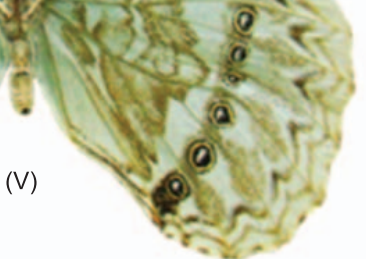

Figure 5. Satyrinae (Morphini) of the Subtropical Atlantic Forest and Araucaria Moist Forest regions of Rio Grande do Sul. 

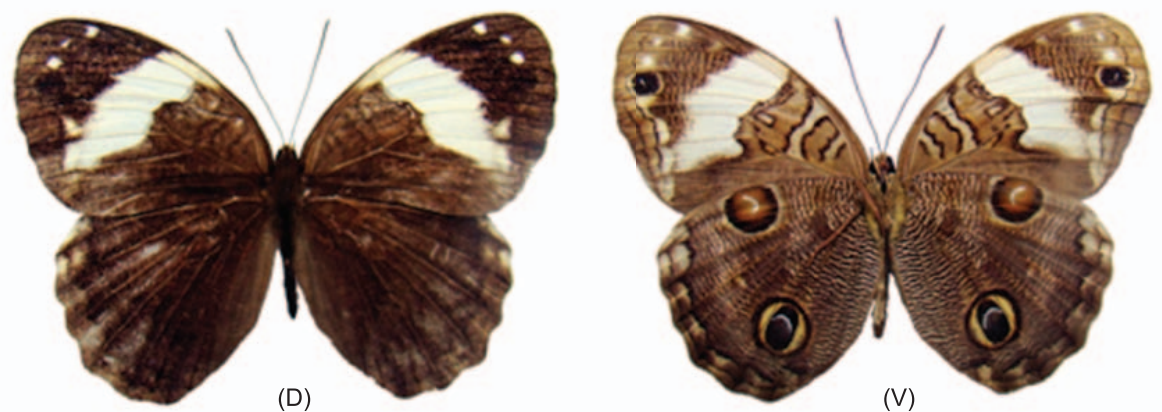

Opoptera fruhstorferi
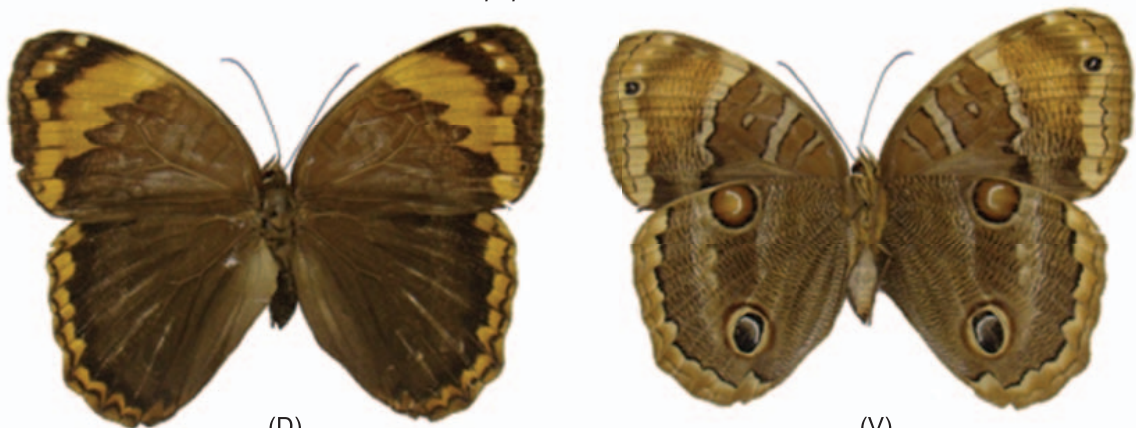

(D)

(V)
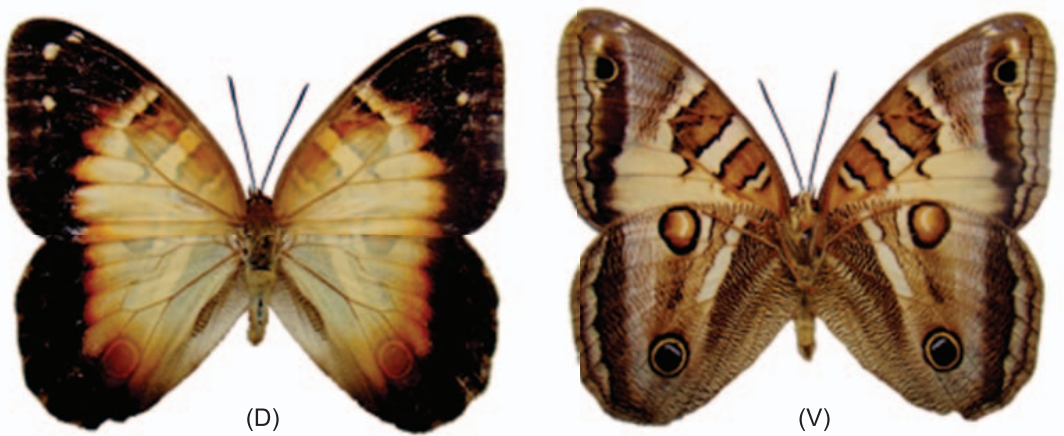

Blepolenis bassus
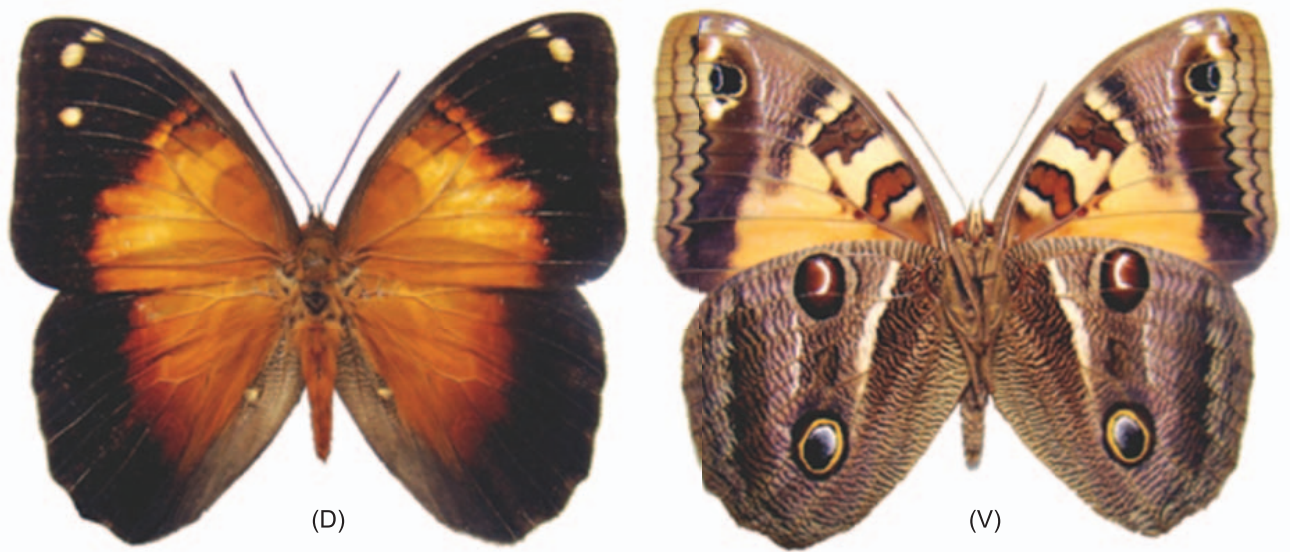

$(0: 9: 1)$

Blepolenis catharinae

Figure 6. Satyrinae (Brassolini) of the Subtropical Atlantic Forest and Araucaria Moist Forest regions of Rio Grande do Sul. 


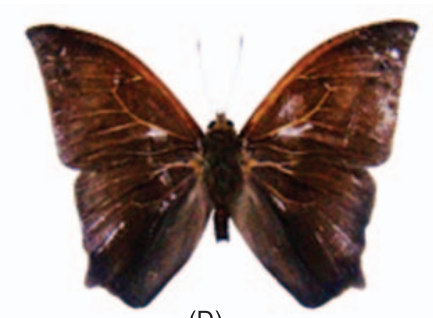

(D)

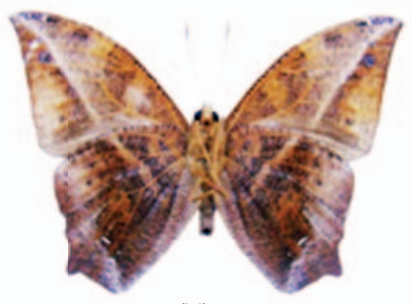

(V)

Narope cyllastros $\lesssim$

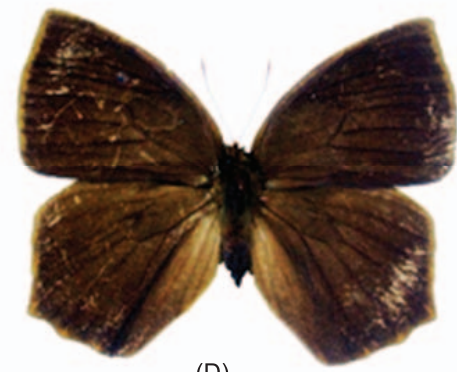

(D)

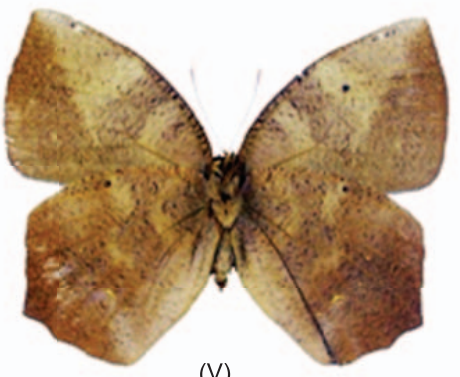

(V)

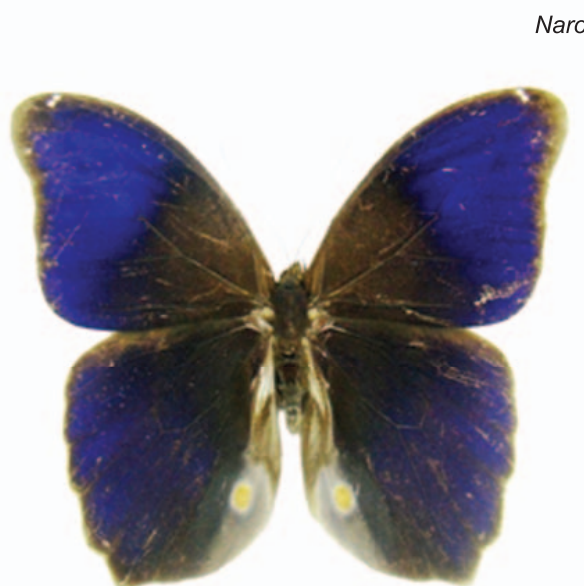

(D)

Narope cyllastros $q$

Eryphanis reevesii 8

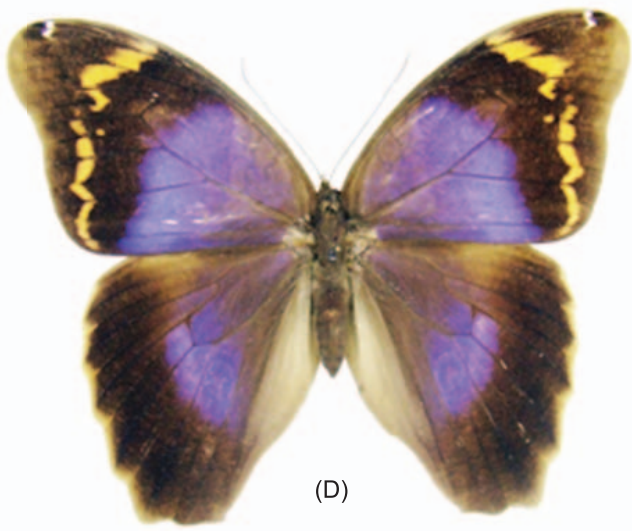

Eryphanis reevesii 우

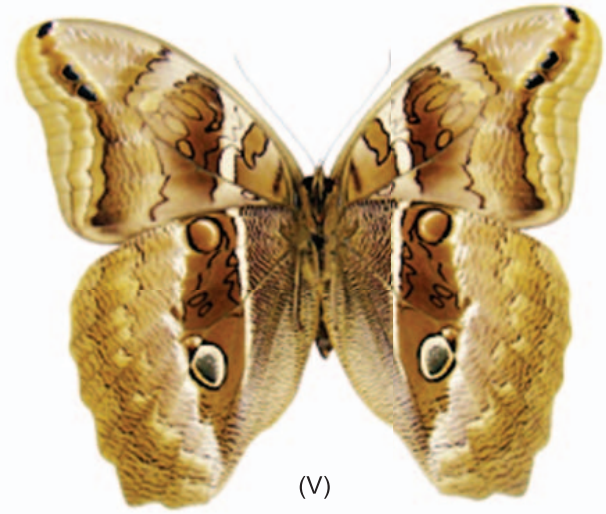

$(0: 9: 1)$

Eryphanis reevesii

Figure 7. Satyrinae (Brassolini) of the Subtropical Atlantic Forest and Araucaria Moist Forest regions of Rio Grande do Sul. 


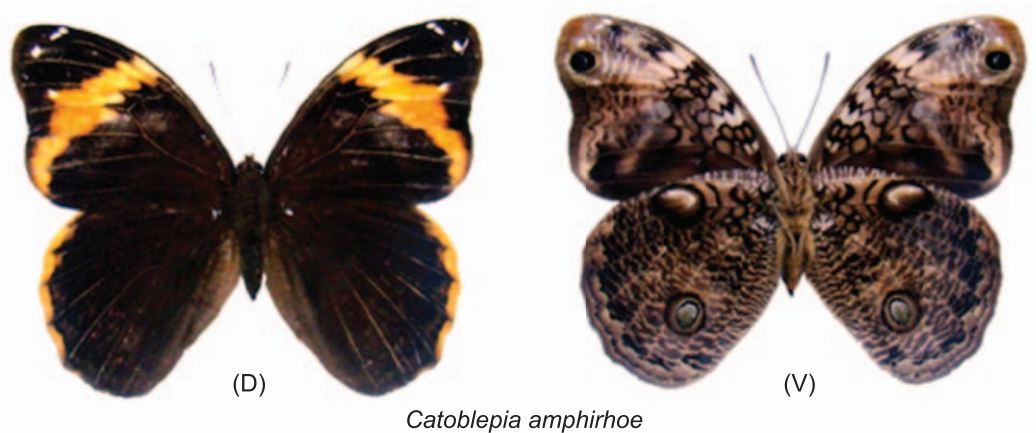

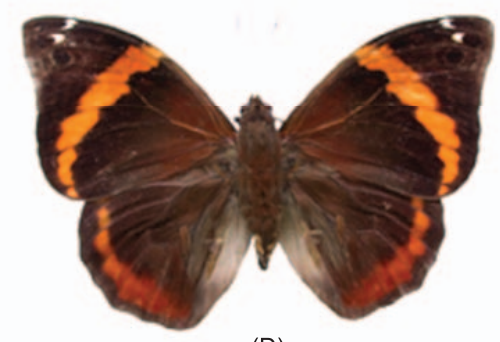

(D)

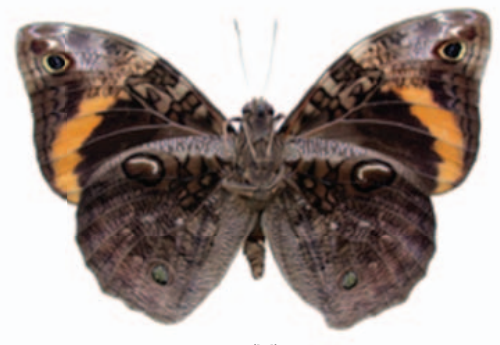

(V)

Opsiphanes invirae remoliatus $\widehat{\partial}$

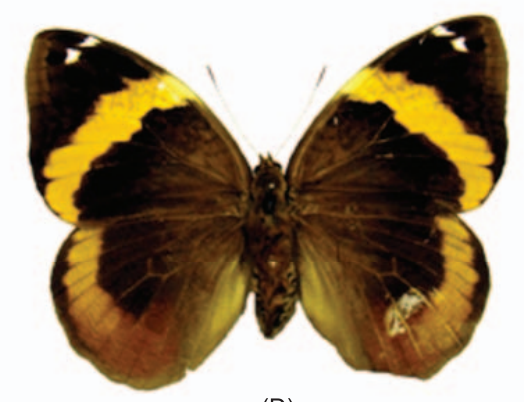

(D)

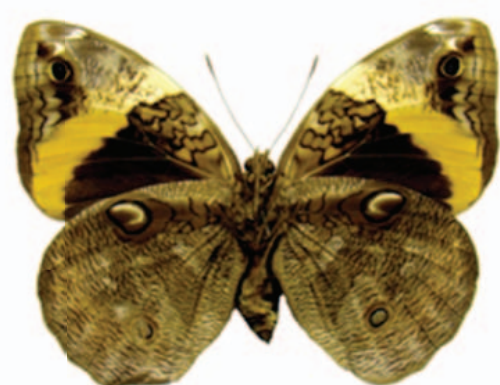

(V)

Opsiphanes invirae remoliatus

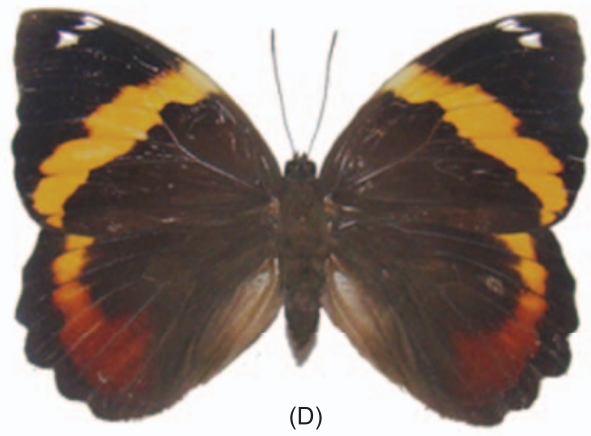

(D)

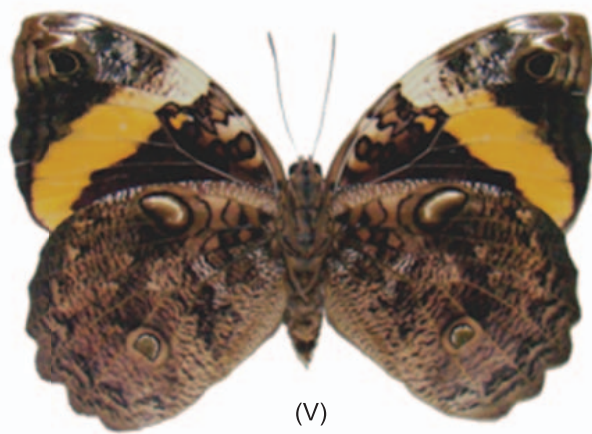

$(0: 7: 1)$

Opsiphanes quiteria quiteria

Figure 8. Satyrinae (Brassolini) of the Subtropical Atlantic Forest and Araucaria Moist Forest regions of Rio Grande do Sul. 


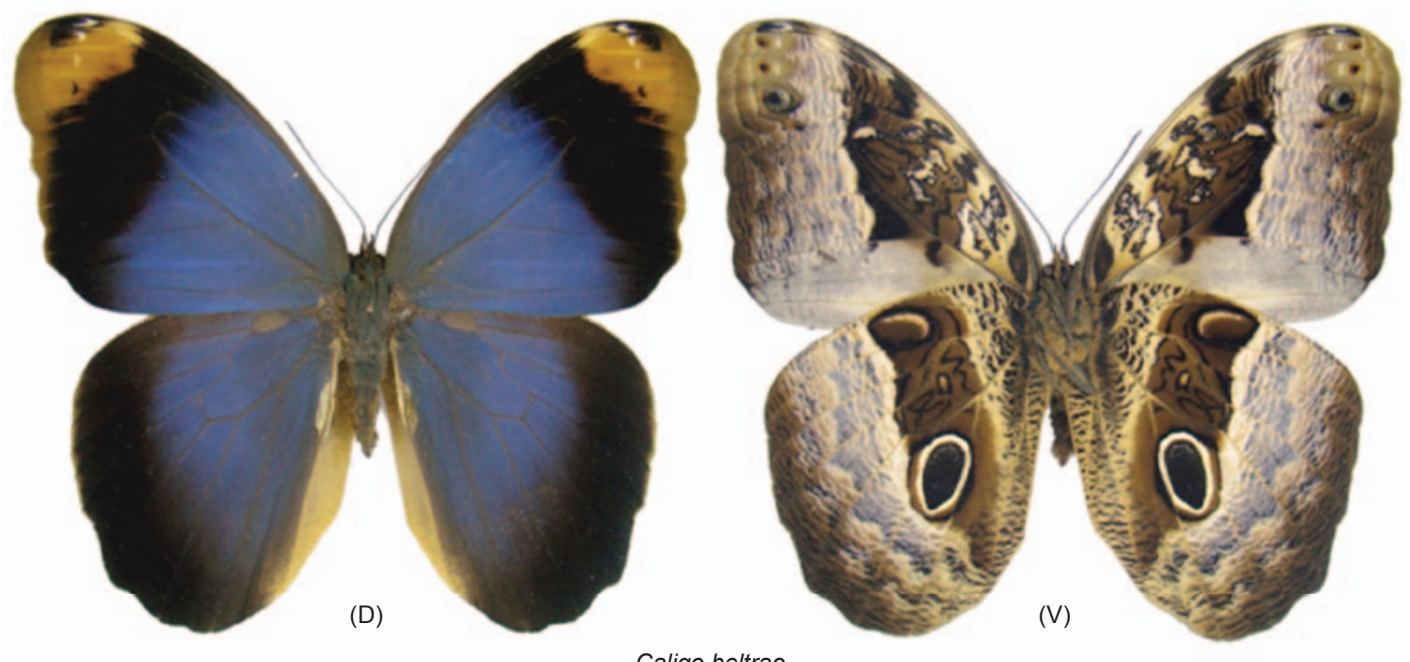

Caligo beltrao

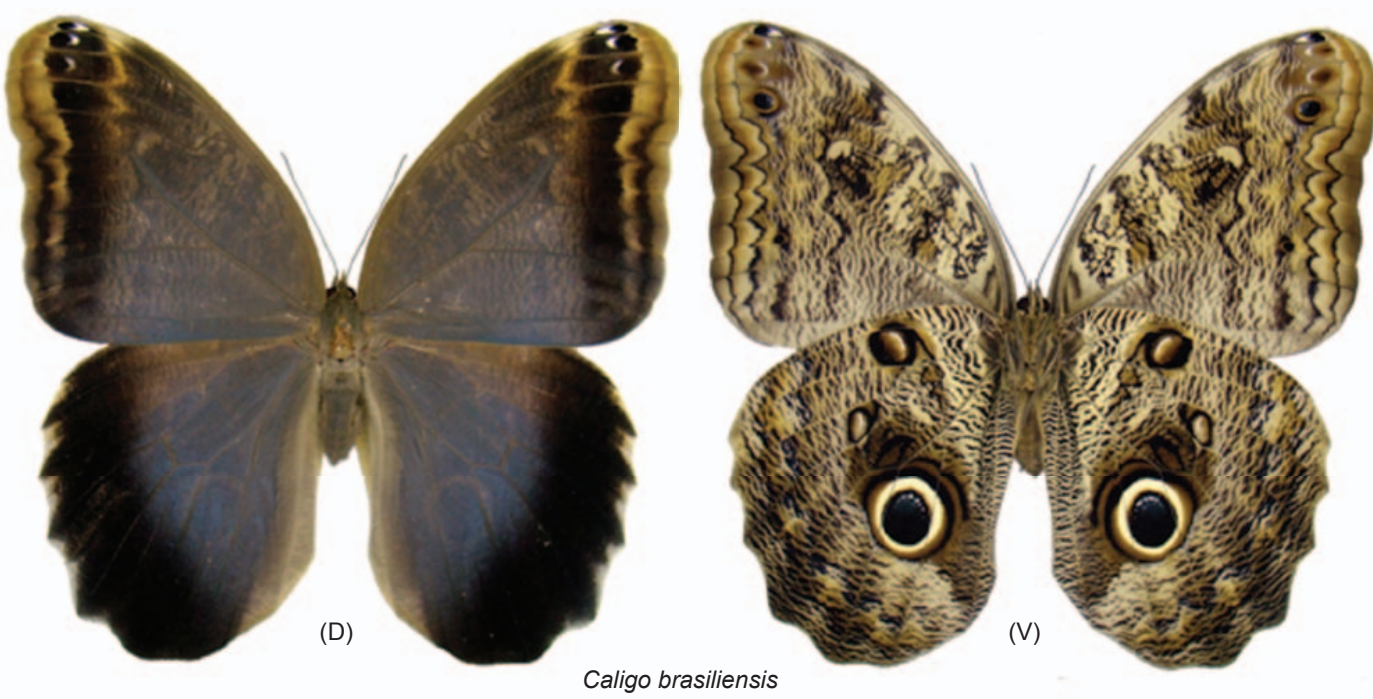

(0:7:1)

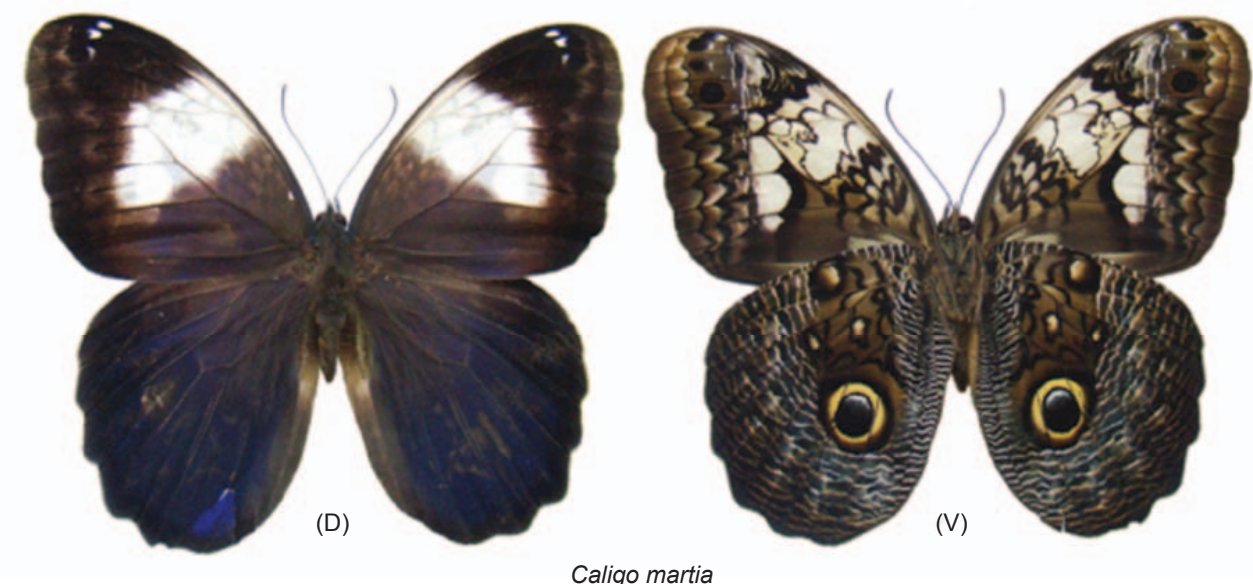

Figure 9. Satyrinae (Brassolini) of the Subtropical Atlantic Forest and Araucaria Moist Forest regions of Rio Grande do Sul. 


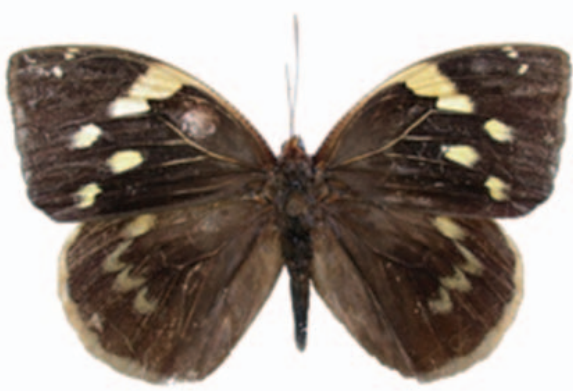

(D)

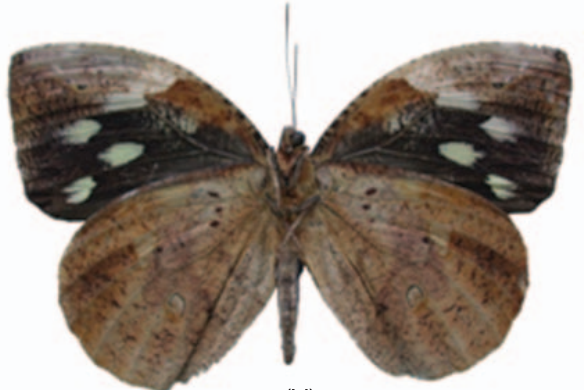

(V)

Dynastor darius darius
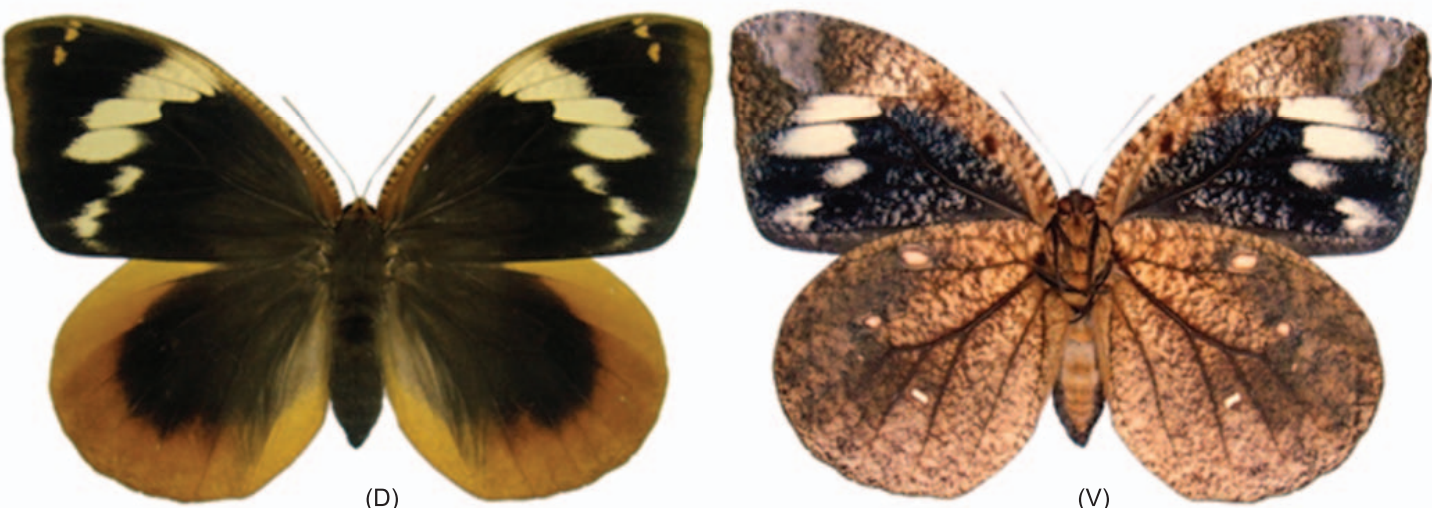

Dynastor napoleon
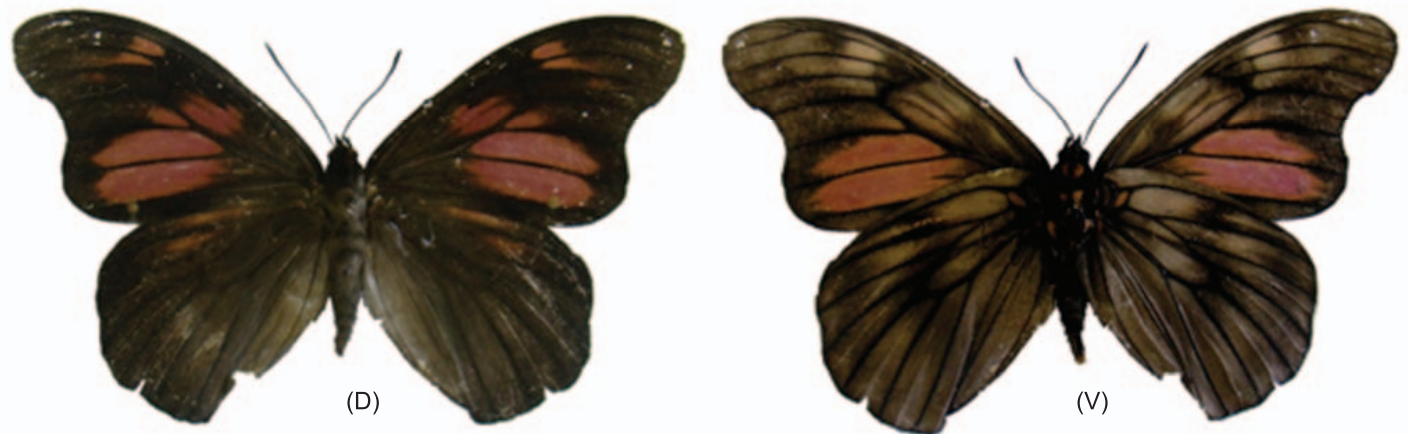

Penetes pamphanis

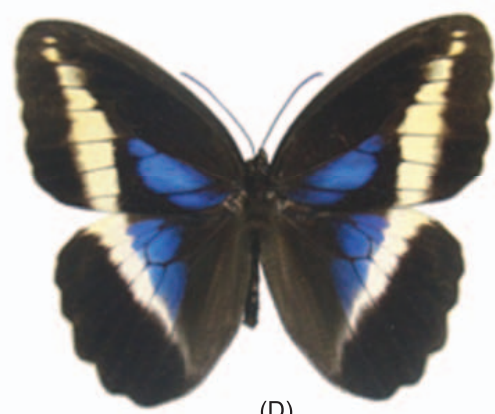

(D)

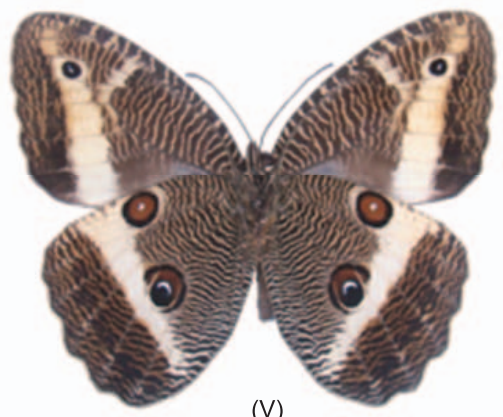

Dasyophthalma rusina

(0:7:1)

Figure 10. Satyrinae (Brassolini) of the Subtropical Atlantic Forest and Araucaria Moist Forest regions of Rio Grande do Sul. 


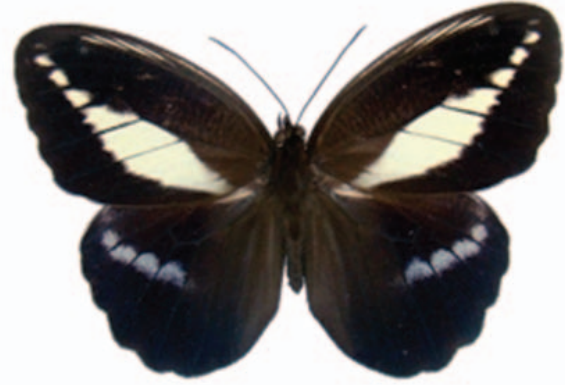

(D)

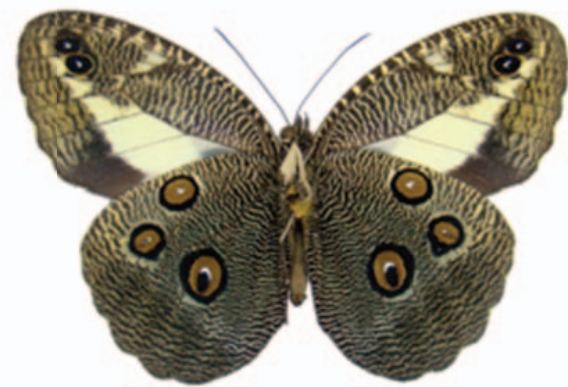

(V)

Dasyophthalma creusa creusa $\partial$
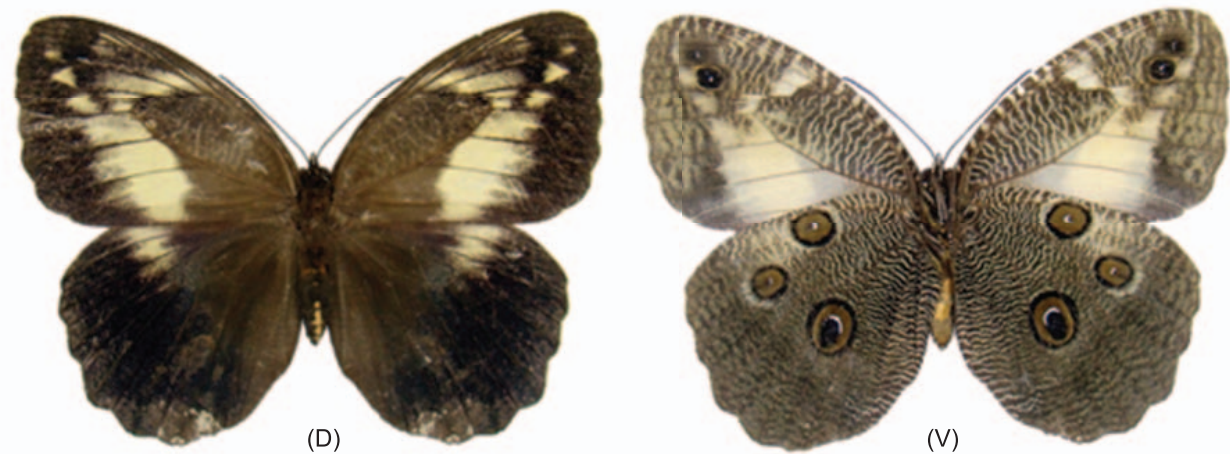

Dasyophthalma creusa creusa

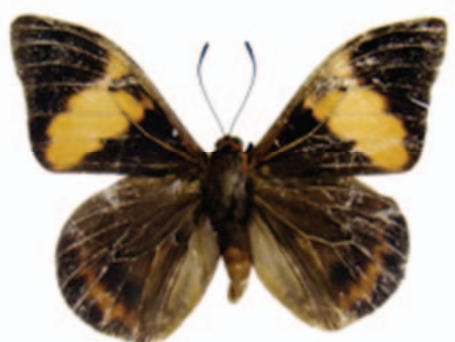

(D)

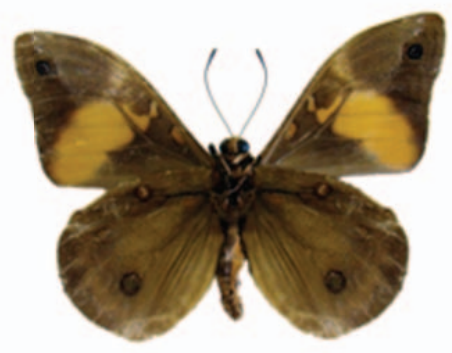

(V)

Brassolis astyra $ठ$

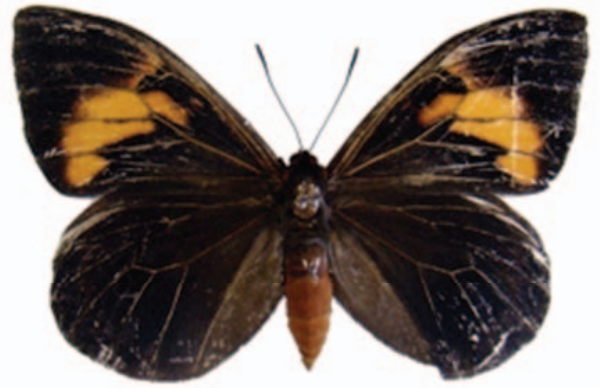

(D)

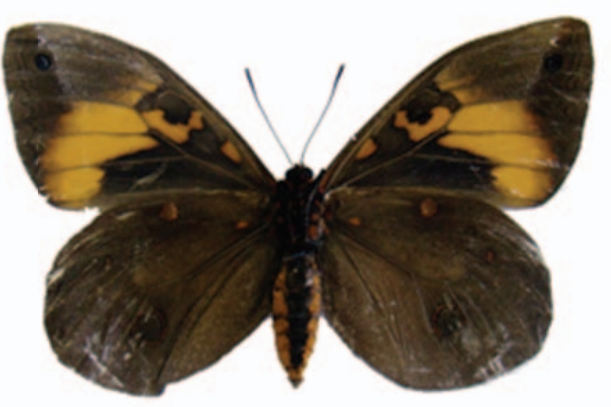

(V)

(0:7:1)

Brassolis astyra 우

Figure 11. Satyrinae (Brassolini) of the Subtropical Atlantic Forest and Araucaria Moist Forest regions of Rio Grande do Sul. 


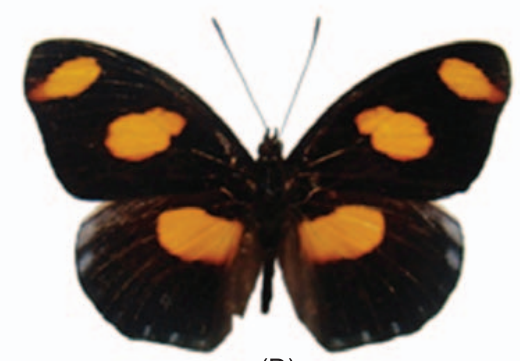

(D)

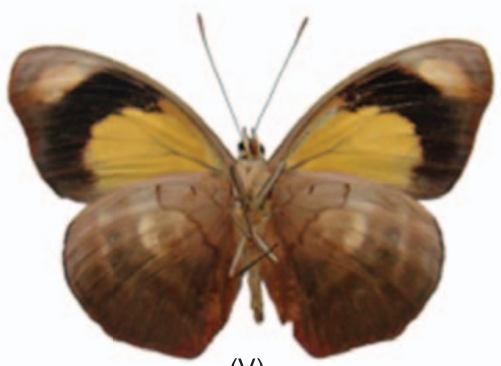

(V)

Catonephele numilia penthia $\widehat{\partial}$
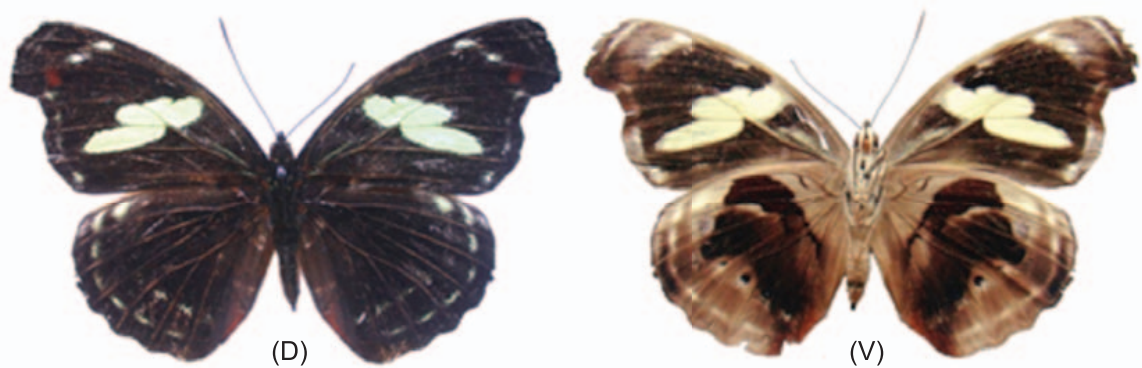

Catonephele numilia penthia +

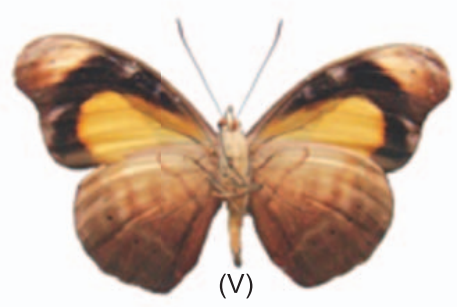

(D)

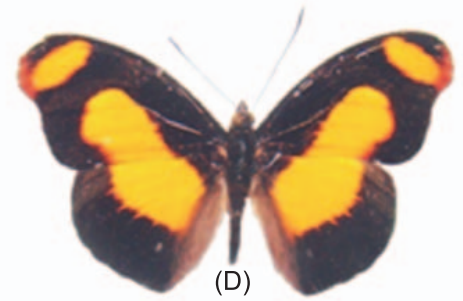

Catonephele sabrina $\widehat{\partial}$
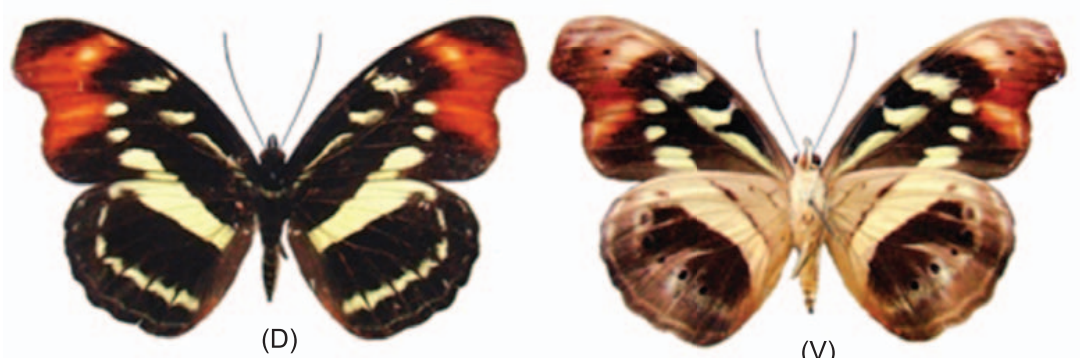

Catonephele sabrina $q$

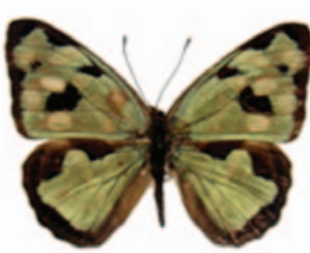

(D)

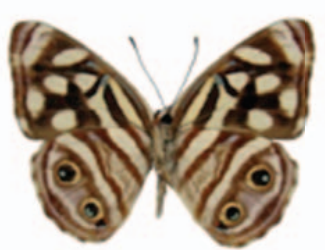

(V)

$(0: 9: 1)$

Dynamine postverta postverta $\widehat{\delta}$

(V)

(V)

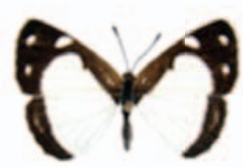

(D)

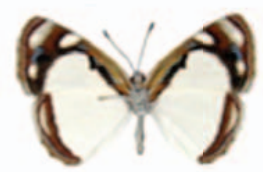

(V)

\section{Dynamine agacles}

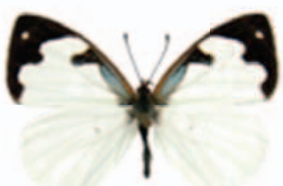

(D)

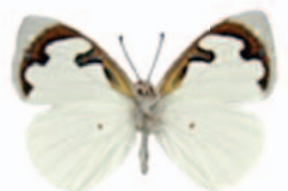

(V)

\section{Dynamine myrrhina}
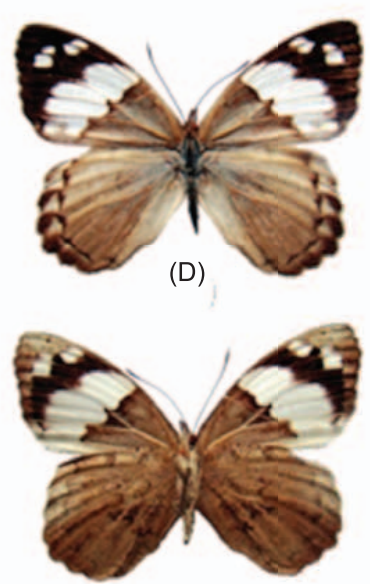

(V)

Eunica eburnea

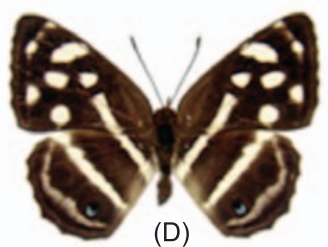

Dynamine postverta postverta 우

Figure 12. Biblidinae (Catonephelini, Eubagini) of the Subtropical Atlantic Forest and Araucaria Moist Forest regions of Rio Grande do Sul. 


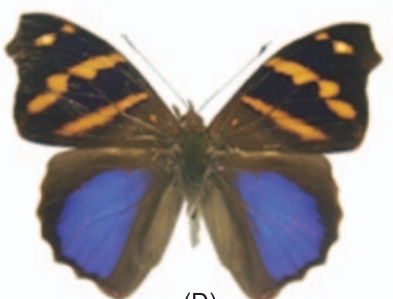

(D)

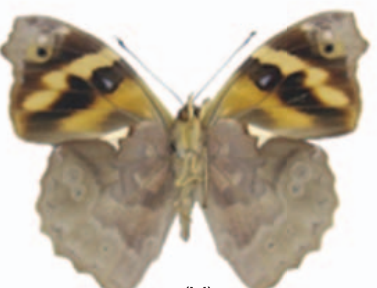

(V)

Epiphile orea orea $\widehat{\delta}$

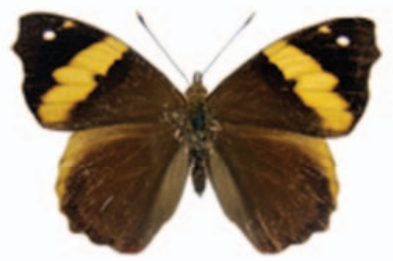

(D)

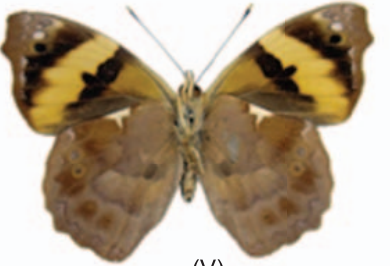

(V)

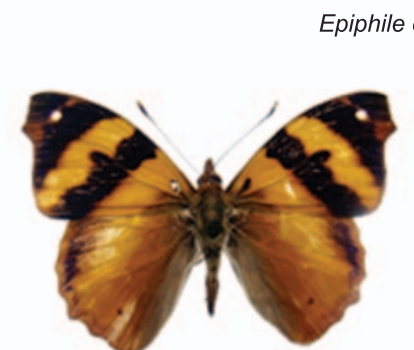

(D)

Epiphile hubneri
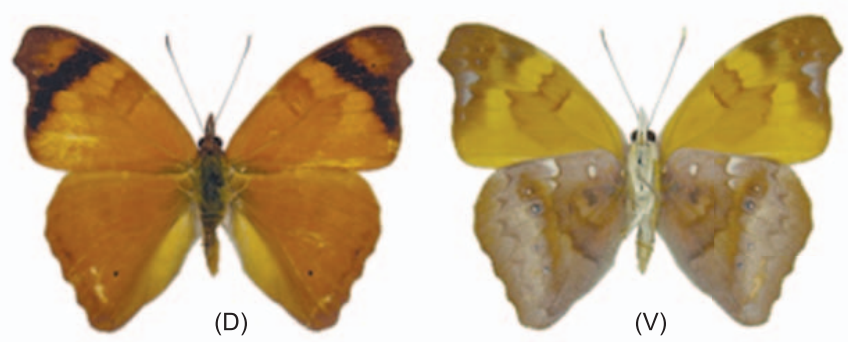

(V)

Temenis laothoe meridionalis

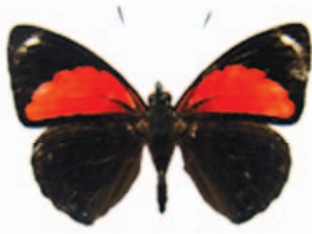

(D)

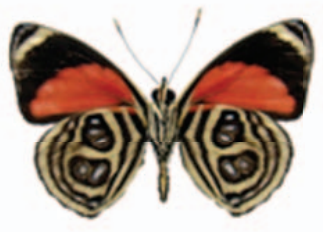

(V)

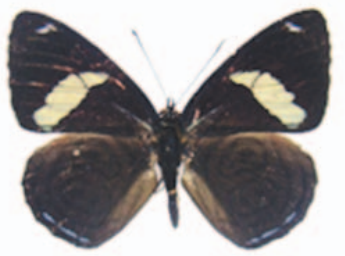

(D)

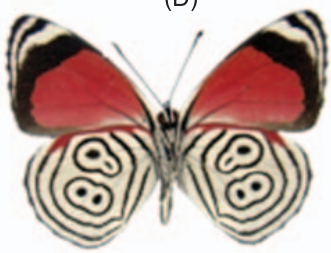

(V)

Diathria clymena meridionalis

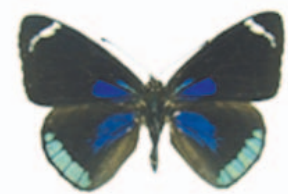

(D)

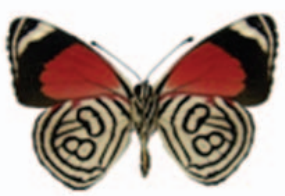

(V)

Diaethria candrena candrena

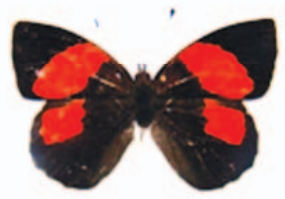

(D)

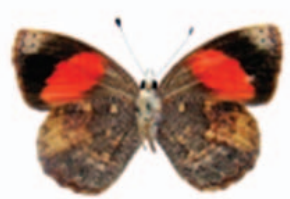

(V)

Haematera pyrame pyrame

(0:9:1)

Callicore pygas eucale

Figure 13. Biblidinae (Epiphilini, Catagrammini) of the Subtropical Atlantic Forest and Araucaria Moist Forest regions of Rio Grande do Sul. 


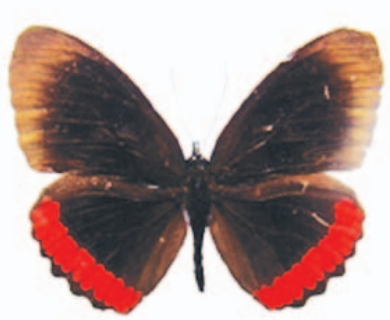

(D)

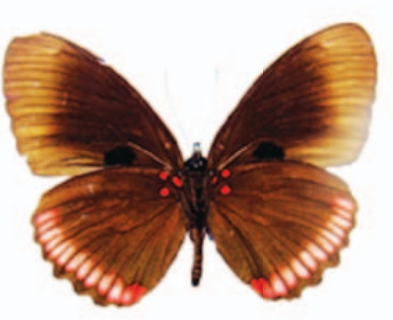

(V)

Biblis hyperia nectanabis

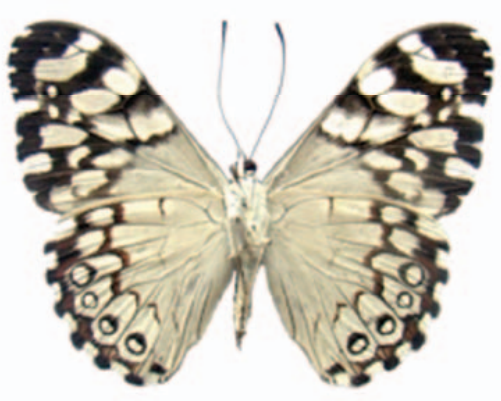

(V)

Hamadryas iphthime

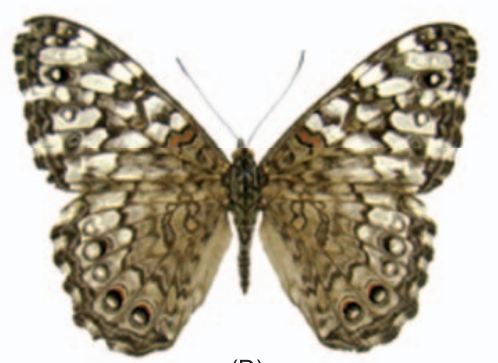

(D)

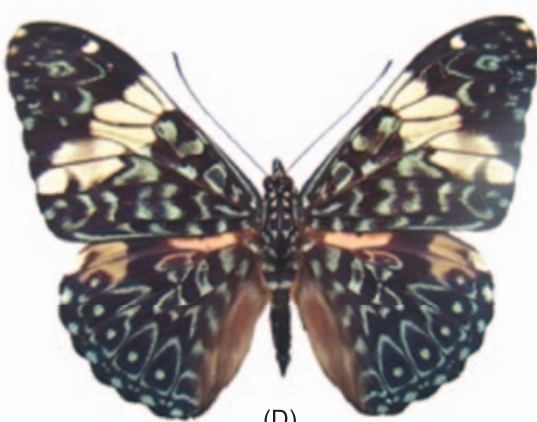

(D)

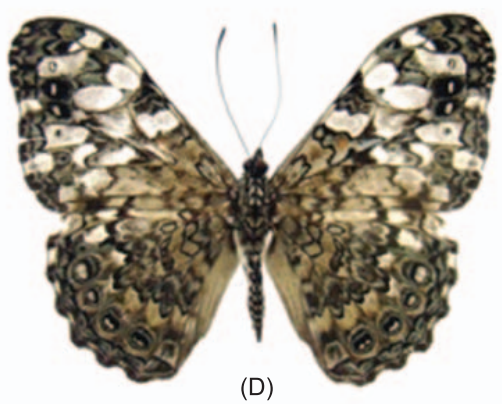

Hamadryas epinome

$(0: 9: 1)$

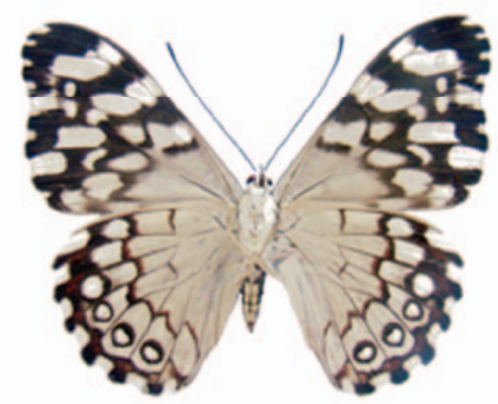

(V)

Hamadryas epinome

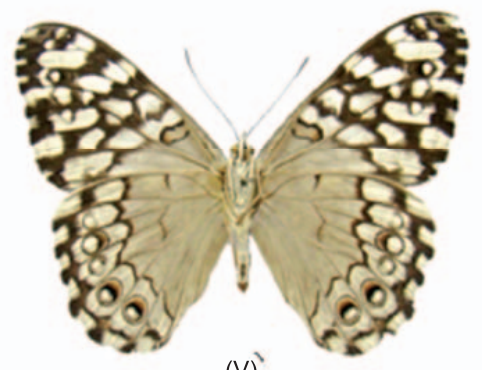

(v)

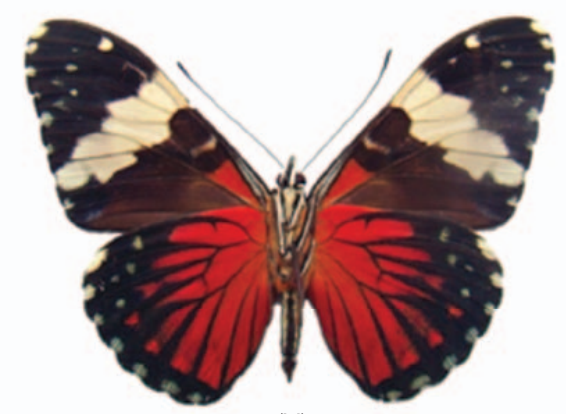

(V)

Hamadryas amphinome amphinome

Figure 14. Biblidinae (Ageroniini, Biblidini) of the Subtropical Atlantic Forest and Araucaria Moist Forest regions of Rio Grande do Sul. 

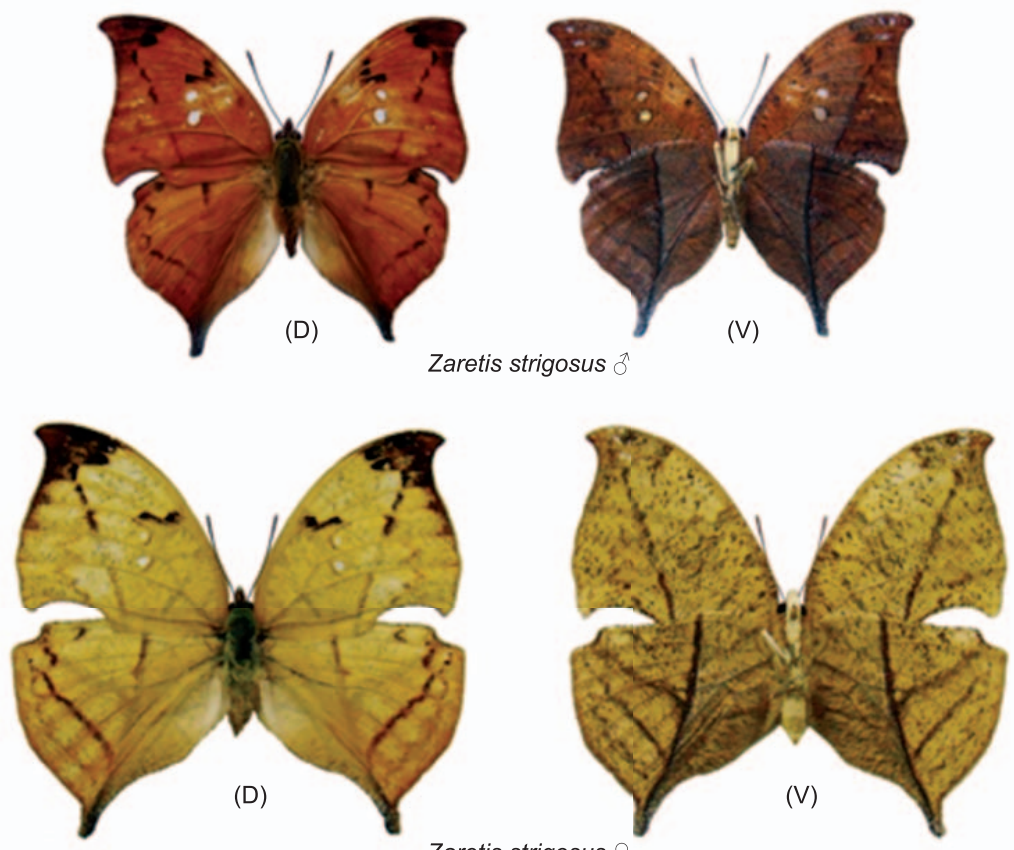

Zaretis strigosus
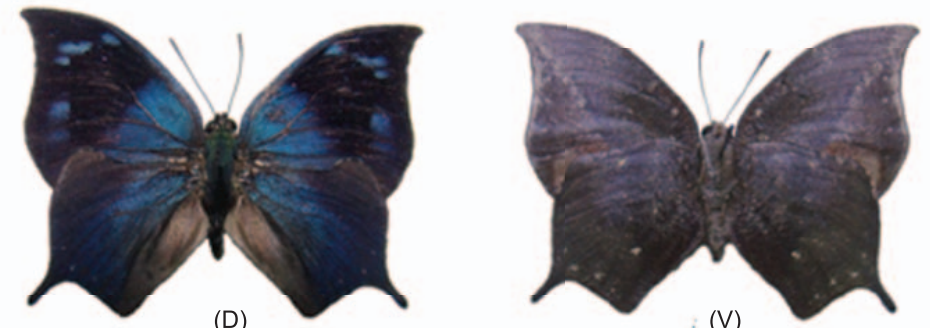

Memphis moruus stheno

( $(\mathrm{)})$
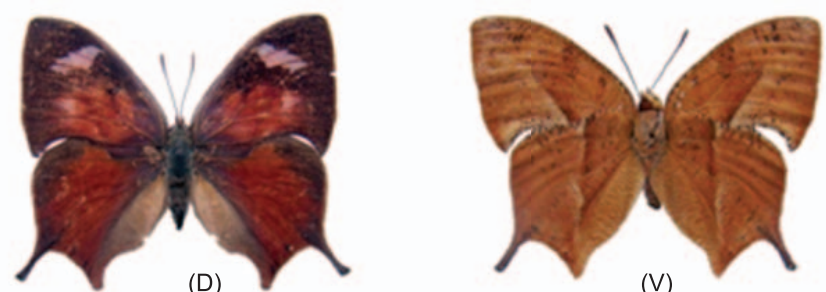

(V)

Memphis hirta
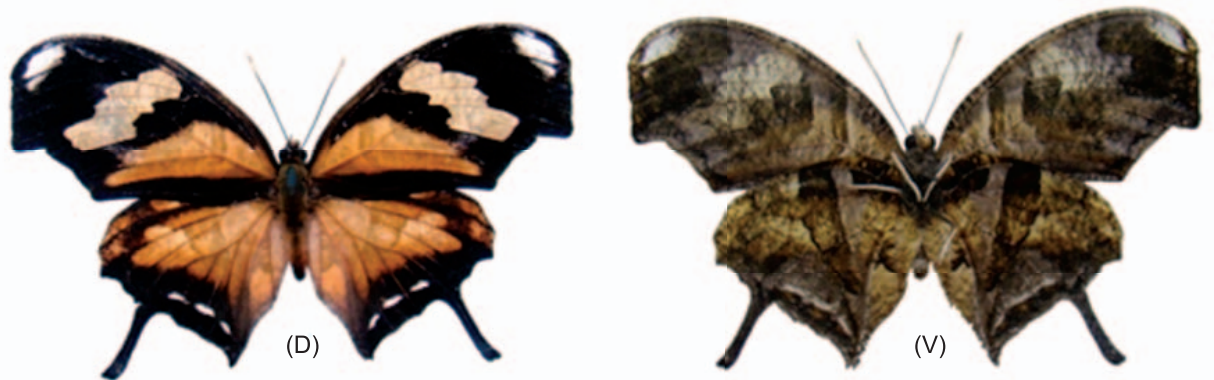

$(0: 9: 1)$

Consul fabius drunii

Figure 15. Charaxinae (Anaeini) of the Subtropical Atlantic Forest and Araucaria Moist Forest regions of Rio Grande do Sul. 

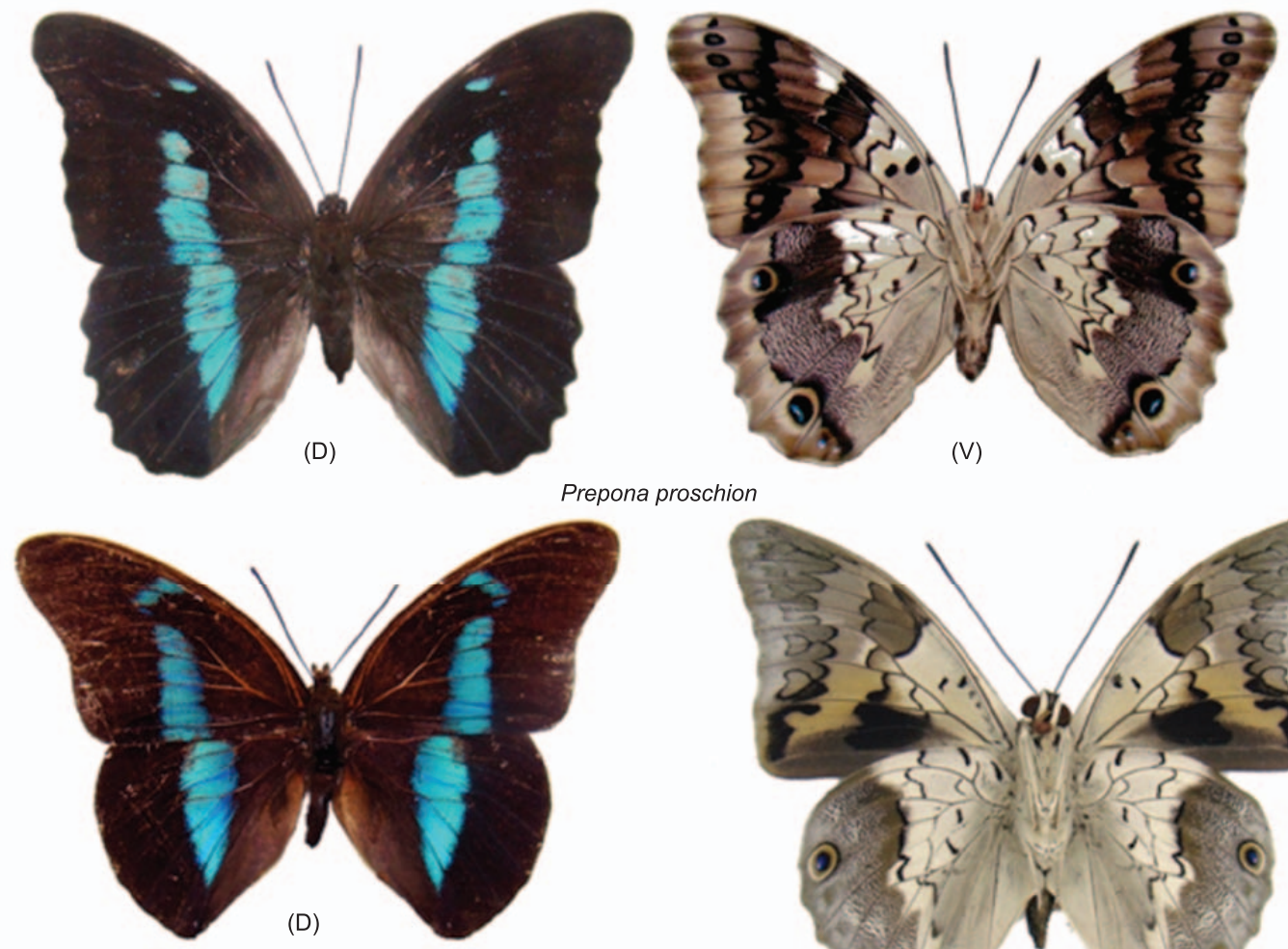

Archaeoprepona chalciope
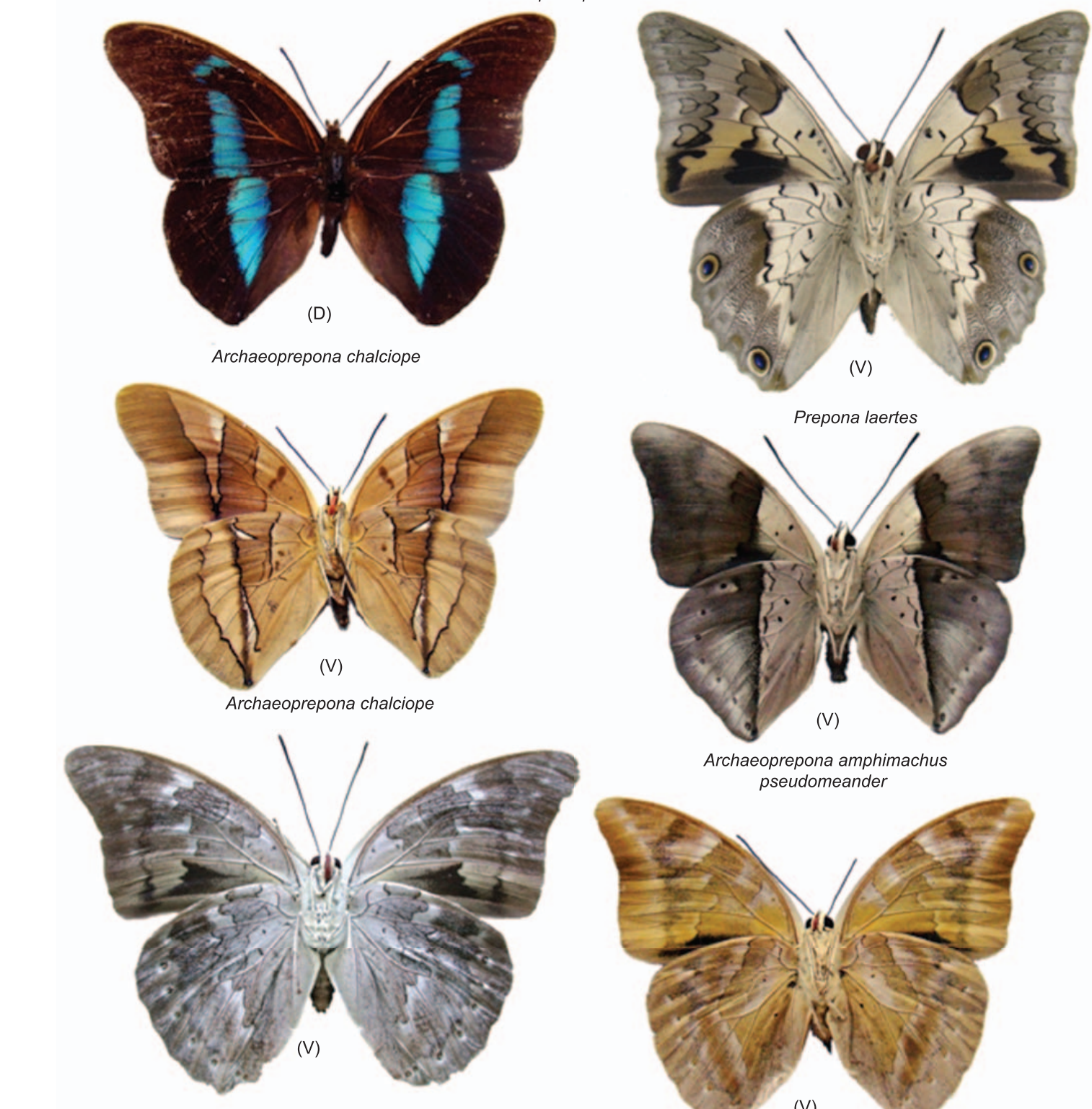

$(0: 9: 1)$

Archaeoprepona demophoon

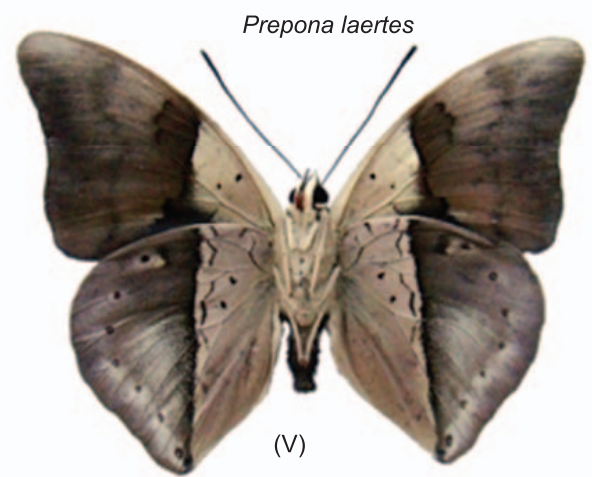

Archaeoprepona amphimachus pseudomeander

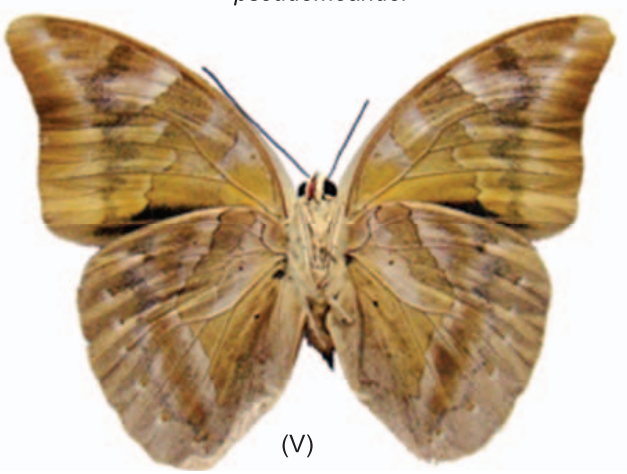

Archaeoprepona demophoon thalpius

Figure 16. Charaxinae (Preponini) of the Subtropical Atlantic Forest and Araucaria Moist Forest regions of Rio Grande do Sul. 


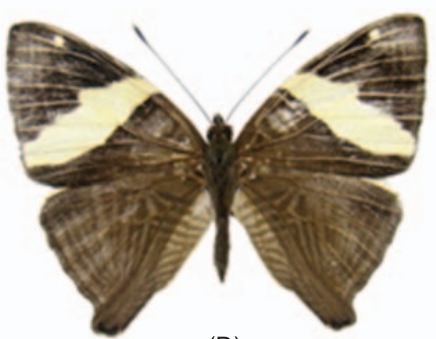

(D)

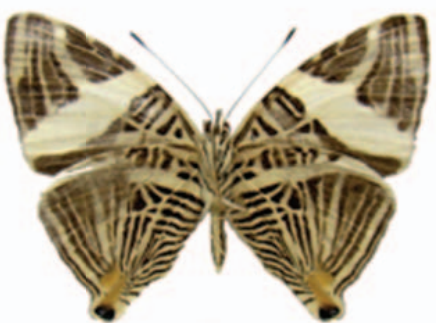

(V)

Colobura dirce dirce
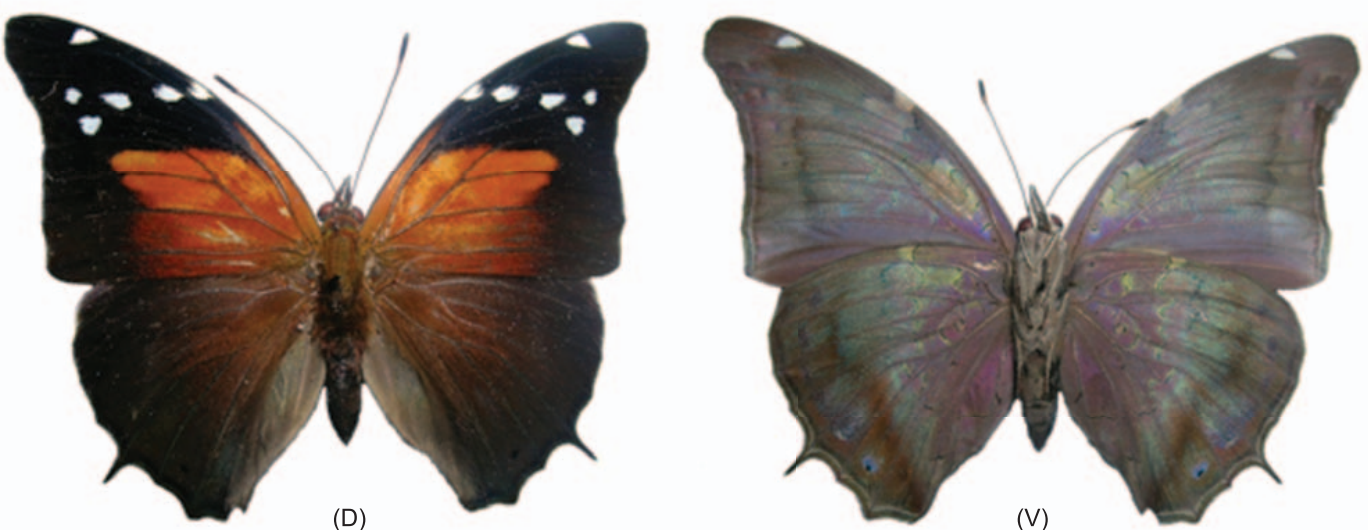

(D)

(V)

Historis acheronta acheronta
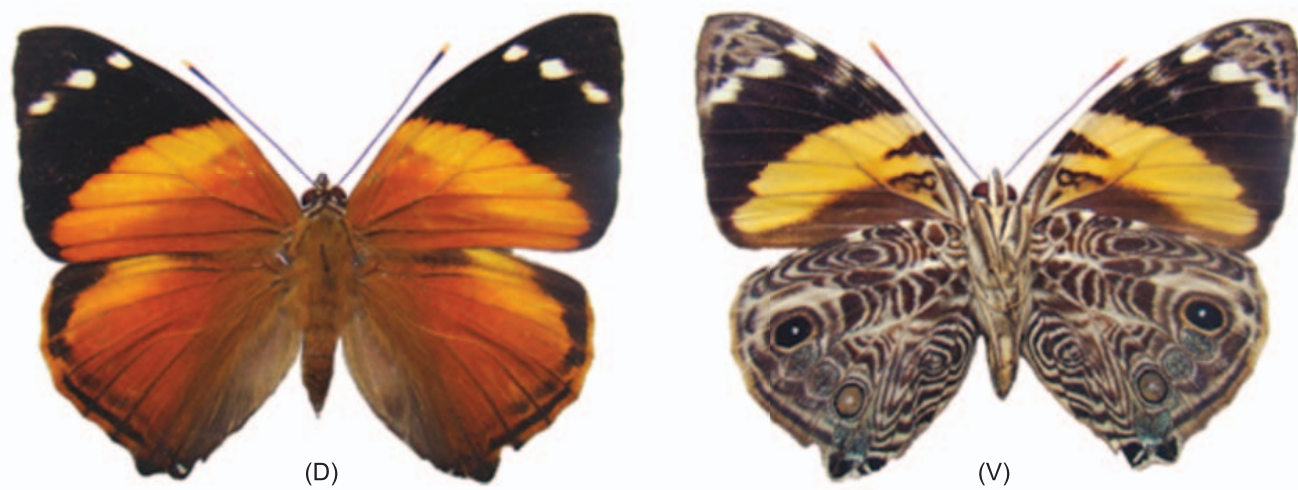

Smyrna blomfildia blomfildia $\precsim$
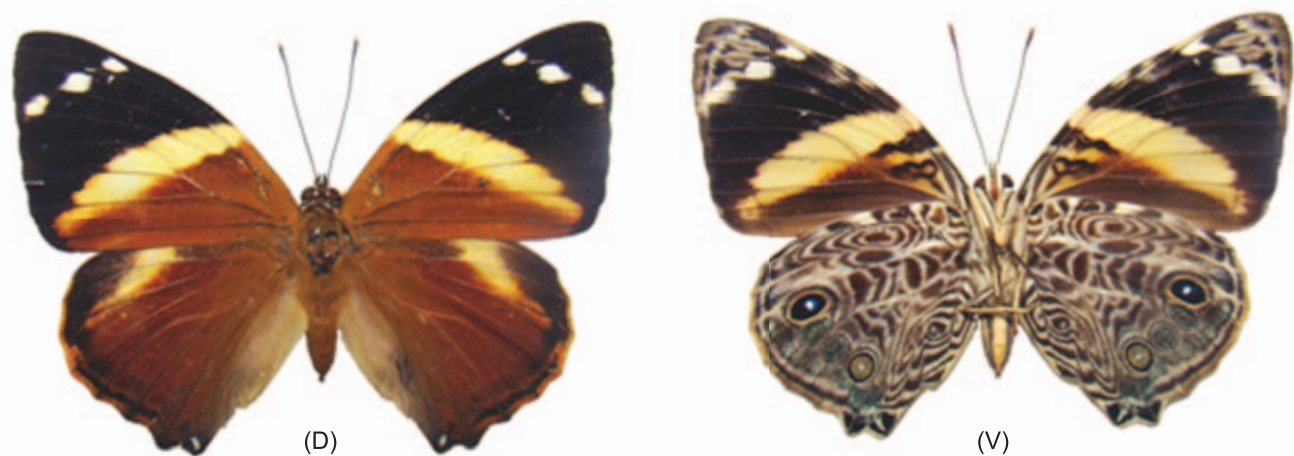

Smyrna blomfildia blomfildia 오

$(0: 9: 1)$

Figure 17. Nymphalinae (Coeini) of the Subtropical Atlantic Forest and Araucaria Moist Forest regions of Rio Grande do Sul. 
Table 1. Species list of fruit-feeding butterflies recorded at the formations of the Atlantic Forest of Rio Grande do Sul. SAF = Subtropical Atlantic Forest; $\mathrm{AMF}=$ Araucaria Moist Forest $\mathrm{S}=$ Species richness .

\begin{tabular}{|c|c|c|c|c|c|}
\hline \multirow[t]{2}{*}{ Family/subfamilies/tribes/species } & \multicolumn{2}{|c|}{ Environments } & \multirow[t]{2}{*}{ Family/subfamilies/tribes/species } & \multicolumn{2}{|c|}{ Environments } \\
\hline & SAF & AMF & & SAF & AMF \\
\hline Nymphalidae $(\mathrm{S}=76)$ & & & Yphthimoides ochracea (Butler, 1867) & $\mathrm{x}$ & $\mathrm{x}$ \\
\hline Satyrinae $(S=45)$ & & & Total S & 34 & 33 \\
\hline Brassolini & & & Charaxinae $(S=10)$ & & \\
\hline Blepolenis bassus (C. Felder \& R. Felder, 1867) & - & $\mathrm{x}$ & Anaeini & & \\
\hline Blepolenis catharinae (Stichel, 1902) & $\mathrm{x}$ & $\mathrm{x}$ & Consul fabius drurii (Butler, 1874) & $\mathrm{x}$ & - \\
\hline Brassolis astyra (Godart, [1824]) & $\mathrm{x}$ & - & Memphis hirta (Weymer, 1907) & - & $\mathrm{x}$ \\
\hline Caligo beltrao (Illiger, 1801) & $\mathrm{x}$ & - & Memphis moruus stheno (Prittwitz, 1865) & $\mathrm{x}$ & $\mathrm{x}$ \\
\hline Caligo brasiliensis (C. Felders, 1862) & $\mathrm{x}$ & - & Zaretis strigosus (Gmelin 1790) & $\mathrm{x}$ & $\mathrm{x}$ \\
\hline Caligo martia (Godart, [1824]) & $\mathrm{x}$ & $\mathrm{x}$ & Preponini & & \\
\hline Catoblepia amphirhoe (Hübner, [1825]) & $\mathrm{x}$ & $\mathrm{x}$ & $\begin{array}{l}\text { Archaeoprepona amphimachus pseudomeander } \\
\text { (Fruhstorfer, 1906) }\end{array}$ & - & $\mathrm{x}$ \\
\hline Dasyophthalma creusa creusa (Hübner, 1821) & $\mathrm{x}$ & - & Archaeoprepona chalciope (Hübner, [1823]) & $\mathrm{x}$ & $\mathrm{x}$ \\
\hline Dasyophtalma rusina (Godart, [1824]) & $\mathrm{x}$ & - & Archaeoprepona demophon thalpius (Hübner, 1814) & $\mathrm{x}$ & $\mathrm{x}$ \\
\hline Dynastor darius darius (Fabricius, 1775) & $\mathrm{x}$ & - & Archaeoprepona demophoon (Hübner, [1814]) & $\mathrm{x}$ & - \\
\hline Dynastor napoleon Doubleday, [1849] & - & $\mathrm{x}$ & Prepona laertes laertes (Hübner, [1811]) & $\mathrm{x}$ & - \\
\hline Eryphanis reevesii (Doubleday, [1849]) & $\mathrm{x}$ & $\mathrm{x}$ & Prepona proschion Fruhstorfer 1904 & - & $\mathrm{x}$ \\
\hline Narope cyllastros Doubleday, [1849] & $\mathrm{x}$ & $\mathrm{x}$ & Total S & 7 & 7 \\
\hline Opoptera fruhstorferi (Röber, 1896) & $\mathrm{x}$ & $\mathrm{x}$ & Biblidinae $(\mathrm{S}=18)$ & & \\
\hline Opoptera sulcius (Staudinger, 1887) & $\mathrm{x}$ & - & Ageroniini & & \\
\hline Opsiphanes quiteria quiteria Staundinger, 1887 & - & $\mathrm{x}$ & Hamadryas amphinome amphinome (Linnaeus, 1767) & $\mathrm{x}$ & $\mathrm{x}$ \\
\hline Opsiphanes invirae remoliatus Fruhstorfer, 1907 & $\mathrm{x}$ & - & Hamadryas epinome (C. Felder \& R. Felder, 1867) & $\mathrm{x}$ & $\mathrm{x}$ \\
\hline Penetes pamphanis Doubleday, [1849] & $\mathrm{x}$ & - & Hamadryas februa februa (Hübner, [1823]) & $\mathrm{x}$ & $\mathrm{x}$ \\
\hline Morphini & & & Hamadryas iphthime (Battes, 1864) & - & $\mathrm{x}$ \\
\hline Morpho aega (Hübner, 1822) & $\mathrm{x}$ & $\mathrm{x}$ & Biblidini & & \\
\hline Morpho anaxibia (Esper, [1801]) & $\mathrm{x}$ & - & Biblis hyperia nectanabis (Fruhstorfer, 1909) & $\mathrm{x}$ & $\mathrm{x}$ \\
\hline Morpho epistrophus catenaria (Perry, 1811) & $\mathrm{x}$ & $\mathrm{x}$ & Catagrammini & & \\
\hline Morpho portis thamyris (Felder \& Felder, 1867) & $\mathrm{x}$ & $\mathrm{x}$ & Callicore pygas eucale (Fruhstorfer, 1916) & $\mathrm{x}$ & - \\
\hline Satyrini & & & Diaethria candrena candrena (Godart, [1824]) & $\mathrm{x}$ & - \\
\hline Capronnieria galesus (Godart, [1824]) & $\mathrm{x}$ & $\mathrm{x}$ & Diaethria clymena meridionalis (H.W.Bates, 1864) & $\mathrm{x}$ & $\mathrm{x}$ \\
\hline Eteona tisiphone (Boisduval, 1836) & $\mathrm{x}$ & $\mathrm{x}$ & Haematera pyrame pyrame Hübner, [1819] & $\mathrm{x}$ & $\mathrm{x}$ \\
\hline Euptychoides castrensis (Schaus, 1902) & - & $\mathrm{x}$ & Catonephelini & & \\
\hline Forsterinaria necys (Godart, [1824]) & $\mathrm{x}$ & $\mathrm{x}$ & Catonephele numilia penthia (Hewitson, 1852) & $\mathrm{x}$ & - \\
\hline Forsterinaria quantius (Godart, [1824]) & $\mathrm{x}$ & $\mathrm{x}$ & Catonephele sabrina (Hewitson, 1852) & $\mathrm{x}$ & $\mathrm{x}$ \\
\hline Godartiana muscosa (Butler, 1870) & $\mathrm{x}$ & $\mathrm{x}$ & Eunica eburnea Fruhstorfer, 1907 & $\mathrm{x}$ & $\mathrm{x}$ \\
\hline Guaianaza pronophila (Butler, 1867) & $\mathrm{x}$ & $\mathrm{x}$ & Epiphilini & & \\
\hline Hermeuptychia hermes (Fabricius, 1775) & $\mathrm{x}$ & $\mathrm{x}$ & Epiphile hubneri Hewitson, 1861 & & $\mathrm{x}$ \\
\hline Moneuptychia griseldis (Weymer, 1911) & - & $\mathrm{x}$ & Epiphile orea orea (Hübner, 1823) & $\mathrm{x}$ & $\mathrm{x}$ \\
\hline Moneuptychia paeon (Godart, [1824]) & $\mathrm{x}$ & $\mathrm{x}$ & Temenis laothoe meridionalis Ebert, 1961 & $\mathrm{x}$ & - \\
\hline Moneuptychia soter (Butler, 1877) & $\mathrm{x}$ & $\mathrm{x}$ & Eubagini & & \\
\hline Moneuptychia sp. & - & $\mathrm{x}$ & Dynamine agacles (Dalman, 1823) & $\mathrm{x}$ & - \\
\hline Pampasatyrus ocelloides (Schaus, 1902) & $\mathrm{x}$ & $\mathrm{x}$ & Dynamine myrrhina (Doubleday, 1849) & $\mathrm{x}$ & $\mathrm{x}$ \\
\hline Pampasatyrus periphas (Godart, [1824]) & - & $\mathrm{x}$ & Dynamine postverta postverta (Cramer, 1779) & $\mathrm{x}$ & - \\
\hline Pampasatyrus quies (Berg, 1877) & - & $\mathrm{x}$ & Total S & 16 & 12 \\
\hline Pampasatyrus reticulata (Weymer, 1907) & - & $\mathrm{x}$ & Nymphalinae $(\mathrm{S}=3)$ & & \\
\hline Paryphthimoides grimon (Godart, [1824]) & $\mathrm{x}$ & - & Coeini & & \\
\hline Paryphthimoides phronius (Godart, [1824]) & $\mathrm{x}$ & $\mathrm{x}$ & Colobura dirce dirce (Linnaeus, 1758) & $\mathrm{x}$ & - \\
\hline Paryphthimoides poltys (Prittwitz,1865) & $\mathrm{x}$ & - & Historis acheronta acheronta (Fabricius, 1775) & $\mathrm{x}$ & - \\
\hline Praepedaliodes phanias (Hewitson, 1862) & $\mathrm{x}$ & $\mathrm{x}$ & Smyrna blomfildia blomfildia (Fabricius, 1781) & $\mathrm{x}$ & $\mathrm{x}$ \\
\hline Prenda clarissa (Freitas \& Mielke, 2011) & - & $\mathrm{x}$ & Total S & 3 & 1 \\
\hline Taygetis ypthima Hübner, [1821] & $\mathrm{x}$ & $\mathrm{x}$ & & & \\
\hline
\end{tabular}




\section{Results and Discussion}

Overall, 8,850 fruit-feeding butterfly individuals, in 76 species belonging to 4 subfamilies of Nymphalidae were recorded in the SAF and AMF (Table 1). In the AMF region of FLONA, between the years of 2006 and 2009, 5,603 individuals in 53 species were recorded. For the SAF in Maquiné, from 2001 to 2002 and from 2006 to 2008, 3,247 butterflies were recorded in 60 species. Thirty-eight species were common to the two sites (Table 1).

Fruit-feeding butterflies represented $49 \%$ of the total richness of Nymphalidae in these areas. This result is similar to the range of 40 to $55 \%$ for fruit-feeding species of this family reported by other studies of tropical forests (Pinheiro \& Ortiz 1992, Daily \& Ehrlich 1995, DeVries et al. 1999, DeVries \& Walla 2001). Satyrinae was the subfamily with the highest species richness with $59.5 \%$ of the representativeness, followed by Biblidinae (23\%), Charaxinae $(13.5 \%)$, and Nymphalinae (4\%). When analyzing the data of SAF and AMF separately, this pattern of representativeness is maintained. Similar patterns of representativeness per subfamily were registered by Uehara-Prado et al. (2004) in the Atlantic Forest of São Paulo State.

During the two-year sampling period that exclusively used bait traps at FLONA, 39 species were recorded. In April 2010, after this sampling period was completed, two new records were obtained. Hamadryas februa (Hübner, 1823) was seen around a trap attracted to the bait, and Dynastor napoleon (Doubleday, 1849), a dead individual was found along a trail of Araucaria reforestation. This species is characteristic of high-altitude forest environments (Brown $\&$ Freitas 2000) and has been recorded in Minas Gerais, Rio de Janeiro (Otero et al. 2000), Paraná (Mielke, pers. comm.) and Rio Grande do Sul (Teston \& Corseuil 2002). The last record of D. napoleon for this region was also in FLONA and dates back to 1959 (which was then called "Estação Florestal de Morrinhos", of the Instituto Nacional do Pinho) (Romanowski et al. 2009). This specimen is deposited at the "Coleção de Lepidoptera" of "Departamento de Zoologia of the Universidade Federal do Rio Grande do Sul". Dynastor napoleon has crepuscular habits. Otero et al. (2000) includes this species in the red list of threatened fauna in Rio de Janeiro State.

Brassolis astyra (Godart, 1824), Dasyophthalma rusina (Godart, 1824) and Morpho anaxibia (Esper, 1801) were only found in the SAF. The species of the Brassolis have a reduced proboscis and was nor attracted to the bait. Dasyophthalma rusina is a new record for Rio Grande do Sul; formerly, it was known to be distributed from Bahia and only as far south as Santa Catarina.

Euptychoides castrensis (Schaus, 1902) and the species of Pampasatyrus have been observed exclusively in the AMF (Teston \& Corseuil 2002, Romanowski et al. 2009, Iserhard et al. 2010). Pampasatyrus ocelloides (Schaus, 1902) and P. periphas (Godart, 1824) have been recorded in other regions of the grasslands of Rio Grande do Sul (Marchiori \& Romanowski 2006, Morais et al. 2007, Paz et al. 2008), while P. quies (Berg, 1877) and P. reticulata (Weymer, 1907) are closely associated with the Campos de Cima da Serra, the adjacent grassland formation that is mingled with the Araucaria Forest of Rio Grande do Sul.

Prenda clarissa Freitas \& Mielke, 2011 was recently described as a new genus and species of Satyrinae. Its distribution includes the Southern states of Rio Grande do Sul, Santa Catarina and Paraná. P. clarissa appears to be linked to highland native grasslands in south Brazil (Campos de Cima da Serra region) (Freitas et al. 2011). Therefore, $P$. clarissa can be treated as potential threatened species due to fragmentation and conversion of its native habitats and should be included in future conservation plans for this biome (Freitas et al. 2011).
This study contains previously unknown information about the fruit-feeding butterflies of the Atlantic Forest of Rio Grande do Sul. It is hoped that these results together with the identification guide, will help the observation and study of fruit-feeding butterflies by amateurs and scientists alike and thus contribute the development of a sense of love for these organisms and their habitats and for their conservation. It also serves as a starting point for future monitoring efforts intended to track future changes in the fruit-feeding butterfly community of this region.

\section{Acknowledgements}

We would like to thank the members of the "Laboratório de Ecologia de Insetos" of UFRGS and other colleagues who helped with this work; the employees and administrators of the Floresta Nacional de São Francisco de Paula/ICMBio, on behalf of Ms. Edenice Brandão and biologist Paola Stumpf of SEMA-RS, for permission to conduct research and for access to the areas; Mr. Sisino and employees of FEPAGRO, for granting permission to conduct sampling on the areas concerned; Dr. André Victor Lucci Freitas and Dra. Carla Penz, for help in identification of specimens and for sharing bibliography. Mr. Alfred Moser, for his collaboration in obtaining some of the images for the guide. This study was financed by $\mathrm{CNPq}$ (process no. 473838/2006-0 and 472175/2007-6), by the PQ grant, process 308292/2007-3 for HPR, and by scholarships from $\mathrm{CNPq}$ and CAPES, for JPS, MOT, and CAI. Butterflies were collected with licenses from IBAMA, No. 070/2006 and No. 11990-1. Contribution $\mathrm{n}^{\circ} 558$ of the Departamento de Zoologia of Universidade Federal do Rio Grande do Sul.

\section{References}

BOND-BUCKUP, G. 2008. Biodiversidade dos Campos de Cima da Serra. Libretos, Porto Alegre.

BROWN, K.S. 1992. Borboletas da Serra do Japi: diversidade, hábitats, recursos alimentares e variação temporal. In História Natural da Serra do Japi: Ecologia e preservação de uma área florestal no sudeste do Brasil (L.P.C. Morellato, ed). Editora da UNICAMP, São Paulo, p.142-186.

BROWN, K. S. 1996. Diversity of Brazilian Lepidoptera: history of study, methods for measurement, and use as indicator for genetic, specific and system richness. In Biodiversity in Brazil, a first approach (C.E.M. Bicudo \& N.A. Menezes, eds). Instituto de Botânica/CNPq, São Paulo, p.223-253.

BROWN, K.S. \& FREITAS, A.V.L. 2000. Atlantic Forest butterflies: indicators for landscape conservation. Biotropica 32: 934-956.

CANALS, G.R. 2000. Butterflies of Buenos Aires. L.O.L.A., Buenos Aires.

CANALS, G.R. 2003. Mariposas de Misiones. L.O.L.A., Buenos Aires.

DAILY, G.C. \& EHRLICH, P.R. 1995. Preservation of biodiversity in small rainforest patches: rapid evaluations using butterfly trapping. Biodivers. Conserv. 4:35-55. http://dx.doi.org/10.1007/BF00115313

DeVRIES, P.J. 1987. The butterflies of Costa Rica and their natural history, Volume1: Papilionidae, Pieridae, Nymphalidae. Princeton University Press, New Jersey.

DeVRIES, P. J. \& WALLA, T.R. 2001. Species diversity and community structure in neotropical fruit-feeding butterflies. Biol. J. Linn. Soc. 74:1-15. http://dx.doi.org/10.1111/j.1095-8312.2001.tb01372.x

DeVRIES, P.J., WALLA, T.R. \& GRENNEY, H.F. 1999. Species diversity in spatial and temporal dimensions of fruit-feeding butterflies from two Ecuadorian rainforests. Biol. J. Linn. Soc. 68:333-353. http://dx.doi. org/10.1111/j.1095-8312.1999.tb01175.x

FERNANDES, A.V. \& BACKES, A. 1998. Produtividade primária em floresta com Araucaria angustifolia no Rio Grande do Sul. Iheringia Sér. Bot. 51(1):63-78.

FERNÁNDEZ DÍAZ, C.I. 2007. Misiones mariposas/ butterflies/ borboletas. Golden Company, Buenos Aires. 
FREITAS, A.V.L., FRANCINI, R.B. \& BROWN, K.S. 2003. Insetos como indicadores ambientais. In Métodos de estudos em biologia da conservação \& manejo da vida silvestre (L. Cullen, R. Rudran \& C. Valladares-Padua, eds.). Editora UFPR, Curitiba, p.125-152.

FREITAS, A.V.L., MIELKE, O.H.H., MOSER, A., SILVA BRANDÃO, K.L. \& ISERHARD, C.A. 2011. A New Genus and Species of Euptychiina (Lepidoptera: Nymphalidae: Satyrinae) from Southern Brazil. Neotrop. Entomol. 40(2): 231-237. http://dx.doi.org/10.1590/ S1519-566X2011000200012

ISERHARD, C.A. 2009. Estrutura e composição da assembléia de borboletas (Lepidoptera: Papilionoidea e Hesperioidea) em diferentes formações da Mata Atlântica do Rio Grande do Sul, Brasil. Tese de Doutorado. Universidade Federal do Rio Grande do Sul, Porto Alegre.

ISERHARD, C.A. \& ROMANOWSKI, H.P. 2004. Lista de espécies de borboletas (Lepidoptera, Papilionoidea e Hesperioidea) da região do Vale do rio Maquiné, Rio Grande do Sul, Brasil. Rev. Bras. Zool. 21(3): 649-662. http://dx.doi.org/10.1590/S0101-81752004000300027

ISERHARD, C.A., QUADROS, M.T., ROMANOWSKI, H.P. \& MENDONÇA JUNIOR, M.S. 2010. Occurrence of butterflies (Lepidoptera: Papilionoidea and Hesperioidea) in different habitats at the Araucaria Moist Forest and the Grasslands in the Basaltic Highlands in Southern Brazil. Biota Neotrop. 10(1): http://www.biotaneotropica. org.br/v10n1/en/abstract?inventory+bn02910012010 (último acesso em 01/07/2010).

KLIMAITIS, J.F. 2000. Cien Mariposas Argentinas. Editorial Albatros, Buenos Aires.

LAMAS, G. 2004. Atlas of Neotropical Lepidoptera. Scientific Publishers, Gainesville. Checklist: Part 4A: Hesperioidea \& Papilionoidea.

MALUF, J.R.T. 2000. Nova classificação climática do Estado do Rio Grande do Sul. Rev. Bras. Agrometeorol. 8(1): 141-150.

MARCHIORI, M.O. \& ROMANOWSKI, H.P. 2006. Borboletas (Lepidoptera: Papilionoidea e Hesperioidea) do Parque Estadual do Espinilho e seu entorno, Rio Grande do Sul, Brasil. Rev. Bras. Zool. 23(4): 1029-1037. http://dx.doi.org/10.1590/S0101-81752006000400007

MORAIS, A.B., ROMANOWSKI, H.P., ISERHARD, C.A., MARCHIORI, M.O. \& SEGUI, R. 2007. Mariposas del sur de Sudamérica (Lepidoptera: Papilionoidea e Hesperioidea). Ciênc. Ambient. 35: 29-46.

NUÑEZ-BUSTOS, E. 2010. Mariposas de la ciudad de Buenos Aires y alrededores. Buenos Aires, Vázquez Mazzini editores.
OTERO, L.S., BROWN, K.S., MIELKE, O.H.H., MONTEIRO, R.F., COSTA, J., MACÊDO, M.V., MACIEL, N.C., BECKER, J., SALGADO, N.C., SANTOS, S.B., MOYA, G.E., ALMEIDA, J.M. \& SILVA, M.D. 2000. Invertebrados terrestres. In A fauna ameaçada de extinção do estado do Rio de Janeiro (H.G. Bergallo, C. F. D. Rocha, M.A.S. Alves \& M. Van Sluys, eds.). Editora UERJ, Rio de Janeiro, p.53-62.

PAZ, A.L.G., ROMANOWSKI, H.P. \& MORAIS, A.B.B. 2008. Nymphalidae, Papilionidae e Pieridae (Lepidoptera: Papilionoidea) da Serra do Sudeste do Rio Grande do Sul, Brasil. Biota Neotrop. 8(1): http:// www.biotaneotropica.org.br/v8n1/pt/abstract?Inventory+bn0160801 (último acesso em 08/03/2010).

PEDROTTI, V.S., BARROS, M.P., ROMANOWSKI, H.P. \& ISERHARD, C.A. 2011. Occurrence of fruit-feeding butterflies (Lepidoptera: Nymphalidae) in a fragment of Araucaria Moist Forest in Rio Grande do Sul State, Brazil. Biota Neotrop. 1(11): http://www.biotaneotropica. org.br/v11n1/en/abstract?article+bn03011012011.

PINHEIRO, C.E.G. \& ORTIZ, J.V.C. 1992. Communities of fruit-feeding butterflies along a vegetation gradient in central Brazil. J. Biogeogr. 19:505-511. http://dx.doi.org/10.2307/2845769

ROMANOWSKI, H.P., ISERHARD, C.A. \& HARTZ, S.M. 2009. Borboletas da floresta com araucária. In Floresta de araucária: ecologia, conservação e desenvolvimento sustentável (C.R. Fonseca, A.F. Souza, A.M. Leal- Zanchet, T. Dutra, A. Backes \& G. Ganade, eds). Holos Editora, Ribeirão Preto, p.229-240.

SOS MATA ATLÂNTICA. Mata Atlântica. http://www.sosmatatlantica.org. br/index.php?section=info\&action=mata (último acesso em 10/05/2010).

TESTON, J.A. \& CORSEUIL, E. 2002. Ninfalídeos (Lepidoptera, Nymphalidae) ocorrentes no Rio Grande do Sul, Brasil. Parte II. Brassolinae e Morphinae. Biociências 10(1):75-84.

UEHARA-PRADO, M., BROWN, K.S. \& FREITAS, A.V.L. 2005. Biological traits of frugivorous butterflies in a fragmented and a continuous landscape in the south Brazilian Atlantic Forest. J. Lepid. Soc. 59(2):96-106.

UEHARA-PRADO, M., FREITAS, A.V.L., FRANCINI, R.B. \& BROWN, K.S. 2004. Guia das borboletas frugívoras da Reserva Estadual do Morro Grande e região de Caucaia do Alto, Cotia (São Paulo). Biota Neotrop. 4(1): http://www.biotaneotropica.org.br/v4n1/pt/abstract?inventory+ BN00504012004 (último acesso em 01/06/2010).

VARGA, A.E. 2000. Mariposas Argentinas. Museo Entomologico Mariposas del Mundo, Buenos Aires.

WAHLBERG, N., LENEVEU, J., KODANDARAMAIAH, U., PEÑA, C., NYLIN, S., FREITAS, A.V.L. \& BROWER, A.V.Z. 2009. Nymphalidae butterflies diversify following near demise at the cretaceous/tertiary boundary. Proc. R. Soc. B. 276:4295-4302. http://dx.doi.org/10.1098/ rspb.2009.1303 